\title{
Evaluation of the Behavior of Two CAD/CAM Fiber-Reinforced Composite Dental Materials by Immersion Tests
}

\author{
Farah Bechir ${ }^{1}$, Simona Maria Bataga ${ }^{2}$, Adrian Tohati ${ }^{3, *}$, Elena Ungureanu ${ }^{4} \mathbb{D}$, Cosmin Mihai Cotrut ${ }^{4} \mathbb{D}$, \\ Edwin Sever Bechir ${ }^{3, *}$, Mircea Suciu ${ }^{3}$ and Diana Maria Vranceanu ${ }^{4}$ (D)
}

1 Doctoral School of Medicine and Pharmacy, George Emil Palade University of Medicine, Pharmacy, Science, and Technology of Targu Mures, 38 Gh. Marinescu Str., 540142 Targu Mures, Romania; farah.bechir@yahoo.com

2 Faculty of Medicine, George Emil Palade University of Medicine, Pharmacy, Science, and Technology of Targu Mures, 38 Gh. Marinescu Str., 540142 Targu Mures, Romania; simonabataga@yahoo.com

3 Faculty of Dental Medicine, George Emil Palade University of Medicine, Pharmacy, Science, and Technology of Targu Mures, 38 Gh. Marinescu Str., 540142 Targu Mures, Romania; mircea.suciu@umfst.ro

4 Faculty of Materials Science and Engineering, Politehnica University of Bucharest, 313 Splaiul Independentei, 060042 Bucharest, Romania; ungureanu.elena14@yahoo.com (E.U.); cosmin.cotrut@upb.ro (C.M.C.); diana.vranceanu@upb.ro (D.M.V.)

* Correspondence: adrian.tohati@umfst.ro (A.T.); bechir.edwin@gmail.com (E.S.B.); Tel.: +40-751-617-021 (A.T.); +40-723-396-969 (E.S.B.)

\section{check for}

updates

Citation: Bechir, F.; Bataga, S.M.; Tohati, A.; Ungureanu, E.; Cotrut, C.M.; Bechir, E.S.; Suciu, M.; Vranceanu, D.M. Evaluation of the Behavior of Two CAD/CAM Fiber-Reinforced Composite Dental Materials by Immersion Tests. Materials 2021, 14, 7185. https:// doi.org/10.3390/ma14237185

Academic Editors: Paola Gandini, Ivana Miletić and Andrea Scribante

Received: 21 October 2021

Accepted: 22 November 2021

Published: 25 November 2021

Publisher's Note: MDPI stays neutral with regard to jurisdictional claims in published maps and institutional affiliations.

Copyright: (c) 2021 by the authors. Licensee MDPI, Basel, Switzerland. This article is an open access article distributed under the terms and conditions of the Creative Commons Attribution (CC BY) license (https:/ / creativecommons.org/licenses/by/ $4.0 /)$.
Abstract: Fiber-reinforced composites are used as restorative materials for prosthetic oral rehabilitation. Gastroesophageal reflux disease (GERD) is an accustomed affection with various oral manifestations. This study aimed to evaluate the behavior of two high-performance CAD/CAM milled reinforced composites (Trinia ${ }^{\mathrm{TM}}$, TriLor) in artificial saliva at different $\mathrm{pH}$ levels through immersion tests, and to determine if changes in mass or surface morphology at variable $\mathrm{pH}$, specific for patients affected by GERD, appear. After investigating the elemental composition and surface morphology, the specimens were immersed in Carter Brugirard artificial saliva for 21 days at different $\mathrm{pH}$ values (5.7, 7.6, and varying the $\mathrm{pH}$ from 5.7 to 3 ). The values of the weighed masses during the immersion tests were statistically processed in terms of mean and standard deviation. Results suggested that irrespective of the medium $\mathrm{pH}$, the two composites presented a similar mass variation in the range of $-0.18( \pm 0.01)-1.82( \pm 0.02) \mathrm{mg}$ after immersion, suggesting their stability when in contact with artificial saliva, an aspect which was also highlighted by scanning electron microscope (SEM) analysis performed on the immersed surfaces. Novel composite biomaterials can be a proper alternative for metal alloys used for prosthetic frameworks in patients suffering from GERD.

Keywords: CAD/CAM; various $\mathrm{pH}$ values; GERD; fiber-reinforced composites; biomaterials; dentistry

\section{Introduction}

Although composites were first used by early Egyptians and Mesopotamian settlers back in $1500 \mathrm{BC}$ [1], they were introduced as dental restorative materials during the late 1950s. Since then, we have witnessed further improvement by developing enhanced composites with long-term durability [2]. Synthetic polymeric materials used as dental biomaterials are compounds used for the treatment, regeneration, or replacement of tissues, organs, or functions of the body, due to their physical, chemical, and mechanical properties [3,4]. Dental biopolymers used in the manufacturing of various prosthetic restorations represent the comprehensive class of biomaterials with large applications in dentistry [5].

Most fiber-reinforced composite (FRC) dental materials contain three distinct constituent parts: (1) the continuous phase (which is also named matrix), (2) the dispersed phase (formed by the fibers, generally glass fibers), and (3) the interphase area [6]. The matrix, which is the majority, takes over the external stress forces on its surface and transforms them at the level of the dispersed phase, which often plays the role of reinforcement 
material, giving greater strength to the composite material [7]. Theoretically, there is an infinite number of possible combinations between different materials, which can be used both as majority phases and as minority phases, in order to obtain a composite material with the desired properties. From a practical point of view, high-performance reinforced composite materials with use in various fields have been obtained, from the aerospace industry to the industry of materials used in medicine and dentistry [8].

Often, the aim of developing a new class of dental reinforced composites was to improve their mechanical strength, to prolong their use, and to acquire other important characteristics, such as specific weight and low cost. Thus, currently, the ratio of resistance/specific weight, and stiffness/specific weight is optimized [7,9]. Among the disadvantages of metals used in dentistry, the potential allergenicity, their weight, density, as well as their long processing time are included. The color of metal restorations has a particular aspect that is different from the gingiva and the teeth color shade. Additionally, metals have great strength, are harder than natural teeth, have a very good thermal conductivity, and inferior thermic insulation in comparison to the natural teeth [10]. Furthermore, free ions released in the oral cavity because of metal corrosion can cause problems regarding the function of the prosthetic restoration and can influence the biological response to the dental alloy [11]. For these reasons (the disputable aesthetics of dental metals and alloys, as well as their physical and chemical properties), the research for other types of dental materials, preferably metal-free, are sustained $[12,13]$. The benefits of metal-free biomaterials for dental restorations are represented by a more natural appearance without metallic elements, for an easier correction of the shade, to match to any tooth, to be highly attractive, and to look and feel like the natural teeth $[14,15]$. The metal-free prosthetic restorations present biocompatibility; therefore, the negative impact of metal on the patient's body is eliminated [10].

Innovations in computer aided design and computer aided manufacture (CAD/CAM) have made the manufacture of new restorative and prosthetic materials possible [16].

Trinia $^{\mathrm{TM}}$ (BICON, Boston, MA, USA) is a fiber-reinforced dental composite for permanent computer aided design and computer aided manufacturing (CAD/CAM) milled dental prosthetic rehabilitations, presented as discs and/or blocks, and it represents an alternative to conventional technological methods. It is a metal-free reinforced dental composite, formed of multidirectional interlacing of a fiberglass and resin matrix in several layers, that has high flexural strength and a flexural modulus of elasticity similar to dentin [17-19]. The properties and versatility of Trinia ${ }^{\mathrm{TM}}$ reinforced composites permit their use for permanent dental prosthetic restorations because of their relatively simple design and manufacturing by using CAD techniques. Trinia ${ }^{\mathrm{TM}}$ can be machined with customary wet- or dry-milling machine systems using nano-diamond burs. The flexural rigidity and the compression strength of Trinia ${ }^{\mathrm{TM}}$ are high despite the minimal CAD/CAM processing time. Trinia ${ }^{\mathrm{TM}}$ can be manufactured extra-orally as well as intra-orally and presents high comfort while wearing because of its light weight $[20,21]$.

TriLor (Bioloren, Saronno, Italy) is a high-performance biocompatible techno-polymer, and its matrix is reinforced with multi-directional glass fibers. It is indicated for a large variety of permanent esthetic metal-free dental prosthetic restorations on implants, such as removable partial dentures, full arch implant supra-structures, and bridge frameworks. Because of its flexing and bending capacity under stress, TriLor represents an ideal milled composite for implant-supported restorations and creates resilient frames/substructures for zirconia, lithium disilicate, acrylics, and composites, due to its characteristics which resemblance natural bone [22-24].

Dental materials interact continuously with the oral environment and with the oral microbiome metabolism. These factors lead to a decreased life of prosthetic restorations used for the oral rehabilitation of patients [25,26]. The gastroesophageal reflux disease (GERD) is an accustomed affection, with approximately $50 \%$ of all adults reporting reflux symptoms at some time during their lives [27]. A lot of oral symptoms appear in GERD 
(i.e., oral dryness, glossalgia, dental erosion, inflammation of the oral mucosa) due to the acidic $\mathrm{pH}$ of oral fluids, increased by the acid reflux [28].

The evaluation models should be pertinent for the in vivo environment to assure that the dental materials will withstand in the oral environment without any depreciation [29,30].

Therefore, the aim of this study was to evaluate the behavior of two high-performance reinforced dental composites (Trinia ${ }^{\mathrm{TM}}$ and TriLor) in artificial saliva at different $\mathrm{pH}$ levels through immersion tests and to determine if changes in mass or surface morphology at variable $\mathrm{pH}$, specific for patients affected by GERD, appear.

\section{Materials and Methods}

\subsection{Sample Preparation}

The experimental samples used in this study were obtained using CAD/CAM technology. The trade name of the selected materials, as well as the manufacturer from which they were purchased along with the sample codification, are presented in Table 1. The samples were obtained in the form of discs with the following dimensions: diameter of $15 \mathrm{~mm}$ and a thickness of $5 \mathrm{~mm}$.

Table 1. Name, sample codification, and manufacturer of materials used.

\begin{tabular}{ccc}
\hline Material Trade Name & Codification & Manufacturer \\
\hline TriniaTM & C1 & BICON Dental Implants (Boston, MA, USA)/https://www.trinia.com/ (Accessed on \\
10 October 2021) [21]
\end{tabular}

\subsection{Morphology and Chemical Composition}

The experimental samples presented in Table 1 were investigated in terms of elemental composition and surface morphology with a scanning electron microscope, equipped with an X-ray energy dispersive spectrometer (SEM-EDS, Phenom ProX, Phenom World, Eindhoven, The Netherlands). The surface morphology and elemental composition were analyzed before and after performing the immersion tests in artificial saliva with different $\mathrm{pH}$ values.

\subsection{Immersion Assay}

The immersion tests represent a non-invasive, facile, and rapid method to evaluate a material behavior in a synthetic body fluid used as testing media. Because the composite biomaterials tested in this study are used in dentistry, artificial saliva was selected as the testing medium. Moreover, considering that not all patients exhibit similar salivary $\mathrm{pH}$ values due to their medical record or other factors, three $\mathrm{pH}$ values were selected to establish if the acidity of the artificial saliva influences the materials' behavior and/or their stability. The $\mathrm{pH}$ values of the artificial saliva used to immerse the samples were selected as follows: 5.7, 7.6, and a varied $\mathrm{pH}(5.7-3)$. In the case of the varied $\mathrm{pH}$, the samples were immersed for 2 days in $\mathrm{pH} 5.7$ and on the third day, it was changed to $\mathrm{pH} 3$ for one day, as can be observed in Figure 1. This cycle was repeated 7 times.

Figure 1 presents the experimental samples of both materials, $\mathrm{C} 1$ and $\mathrm{C} 2$, used in this study and a schematic illustration of the $\mathrm{pH}$ selected for the artificial saliva.

The immersion assays were carried out for 21 days at a constant temperature of $37 \pm 0.1^{\circ} \mathrm{C}$ by using a Memmert IF55 incubator (Memmert $\mathrm{GmbH}$, Büchenbach, Germany) in Carter Brugirard artificial saliva with the chemical composition presented in Table 2. 


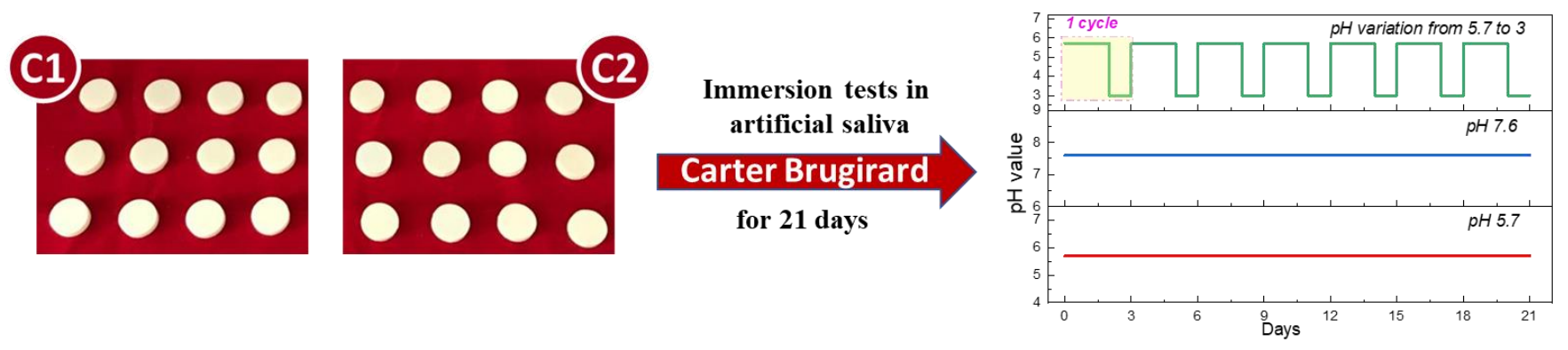

Figure 1. Images of the experimental samples $\left(\mathrm{C} 1-\right.$ Trinia $^{\mathrm{TM}}$ and $\mathrm{C} 2-$ TriLor $)$ and $\mathrm{pH}$ value of the artificial saliva.

Table 2. Chemical composition of Carter Brugirard artificial saliva.

\begin{tabular}{cc}
\hline Chemical Substances & Quantity/L (g) \\
\hline $\mathrm{Na}_{2} \mathrm{HPO}_{4}$ & 0.19 \\
\hline $\mathrm{NaCl}$ & 0.70 \\
\hline $\mathrm{KSCN}$ & 0.33 \\
\hline $\mathrm{KH}_{2} \mathrm{PO}_{4}$ & 0.26 \\
\hline $\mathrm{NaHCO}_{3}$ & 1.50 \\
\hline Ureea & 1.30 \\
\hline
\end{tabular}

Prior to immersion, the containers in which the tests were performed were irradiated with a UV-C lamp (280-100 nm) (Segula BmbH, Horb am Neckar, Germany) to sterilize them, thus, preventing the formation of biofilms on their surface during the tests.

The materials' behavior in artificial saliva with different $\mathrm{pH}$ values was evaluated by monitoring their mass loss/gain at different time intervals (3, 7, 14, and 21 days) with a Kern ALT 100-5 am balance with an accuracy of $0.01 \mathrm{mg}$. The samples were removed from the medium at predetermined intervals and were cleaned with distilled water, dried in hot air, and subsequently dried for $5 \mathrm{~h}$ at a temperature of $80^{\circ} \mathrm{C}$ in a Memmert UF55 oven (Memmert $\mathrm{GmbH}$, Büchenbach, Germany). They were then kept in a desiccator until they were weighed [31]. During the tests, the artificial saliva media were changed periodically (every 2 days) to permanently ensure the ionic concentration of the solutions and also to prevent the formation of biofilms.

For immersion assay, a number of 4 specimens of each material and the mass measurements were repeated 5 times for each sample. The samples mass variation was calculated using the mathematical formula below:

$$
\Delta \mathrm{m}=\mathrm{m}_{\mathrm{f}}-\mathrm{m}_{\mathrm{i}}(\mathrm{mg})
$$

where:

- $\Delta \mathrm{m}$ represents the mass variation;

- $\mathrm{m}_{\mathrm{f}}$ is the mass of the sample after immersion;

- $\mathrm{m}_{\mathrm{i}}$ is the initial mass of the sample.

After monitoring the mass gain/loss, the samples were analyzed in terms of morphology by SEM, to establish if the $\mathrm{pH}$ value has an impact on the materials' behavior.

\section{Results}

3.1. Characterization of Fiber-Reinforced Resin Materials before Immersion Tests

\subsubsection{Morphology}

The surface morphology obtained by SEM of the two fiber-reinforced resin materials used in the study, $\mathrm{C} 1$ and $\mathrm{C} 2$, are presented in Figures 2 and 3. Both materials consist of a polymer matrix of epoxy resin in which multidirectional oriented glass fibers are integrated. Thus, as can be seen in Figures 2 and 3, both materials have reinforcing elements in the form of fibers, arranged differently, having a "textile fabric" appearance, fixed in epoxy resin. 


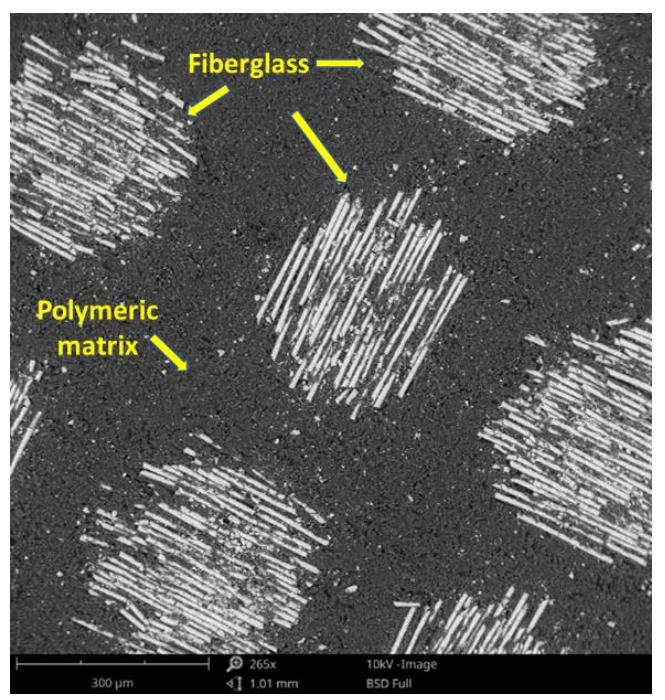

(a)

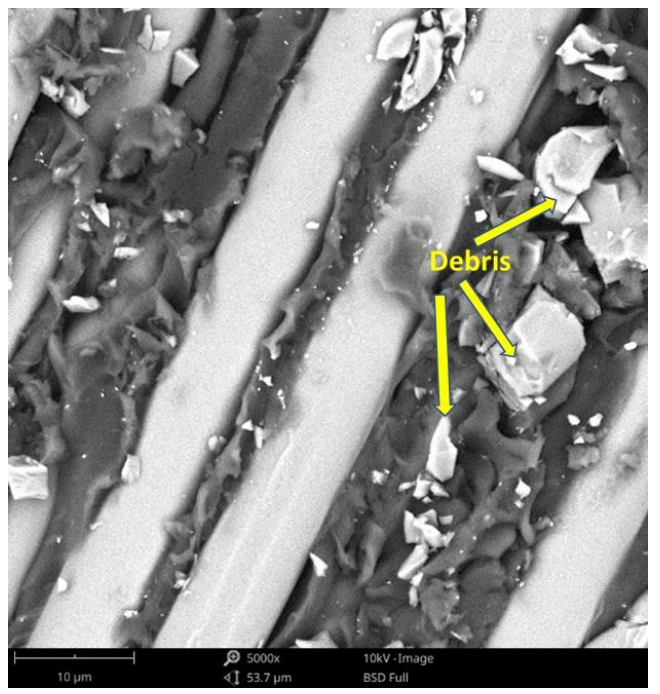

(c)

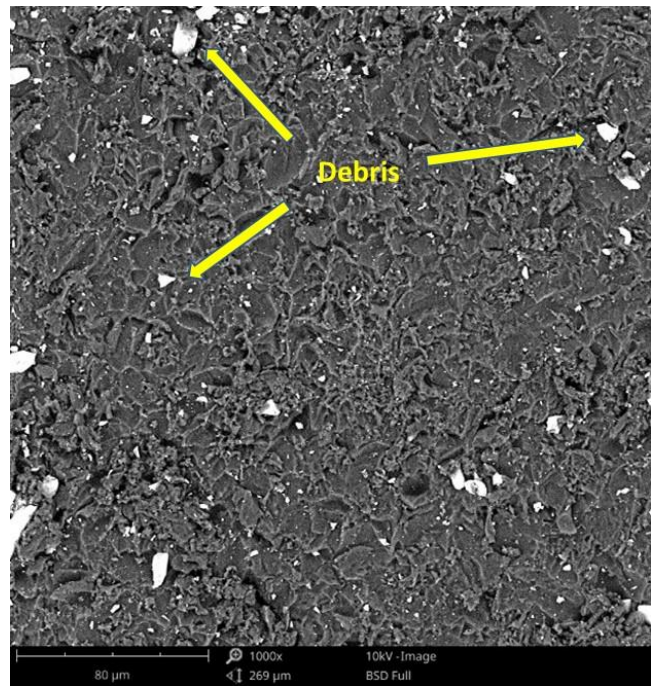

(e)

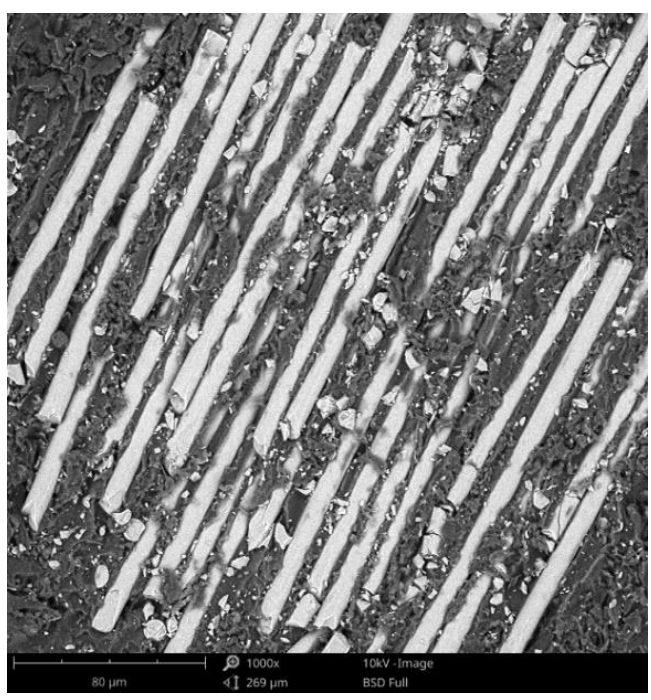

(b)

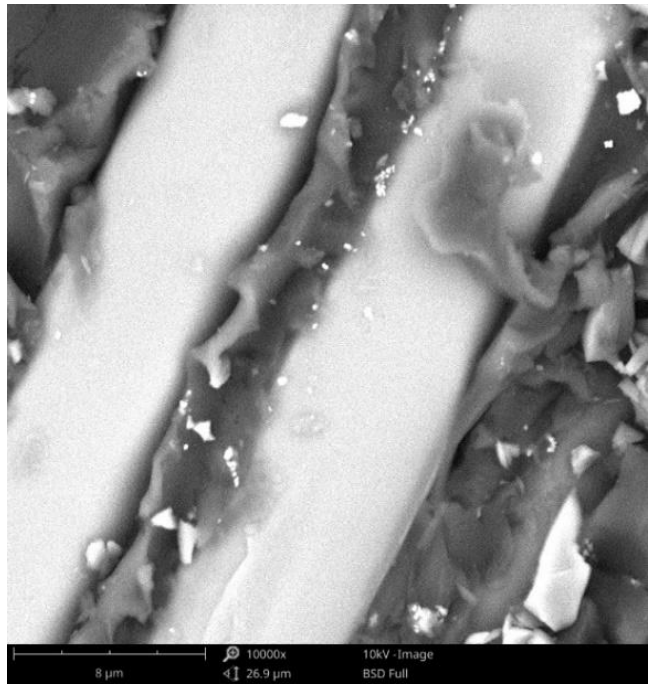

(d)

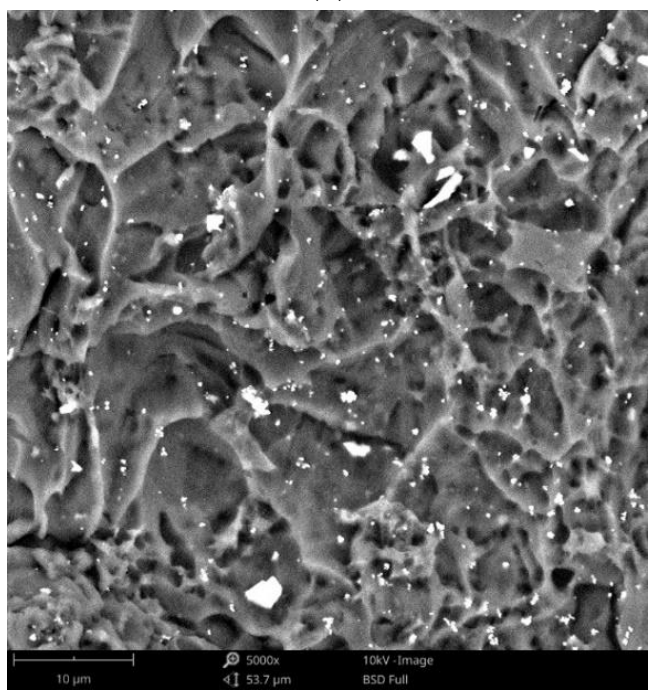

(f)

Figure 2. SEM images of sample C1 surfaces: (a) fiberglass at $265 \times$; (b) fiberglass at $1000 \times$; (c) fiberglass at $5000 \times$; (d) fiberglass at $10,000 \times$; (e) polymer matrix at $1000 \times$; (f) polymer matrix at $5000 \times$. 


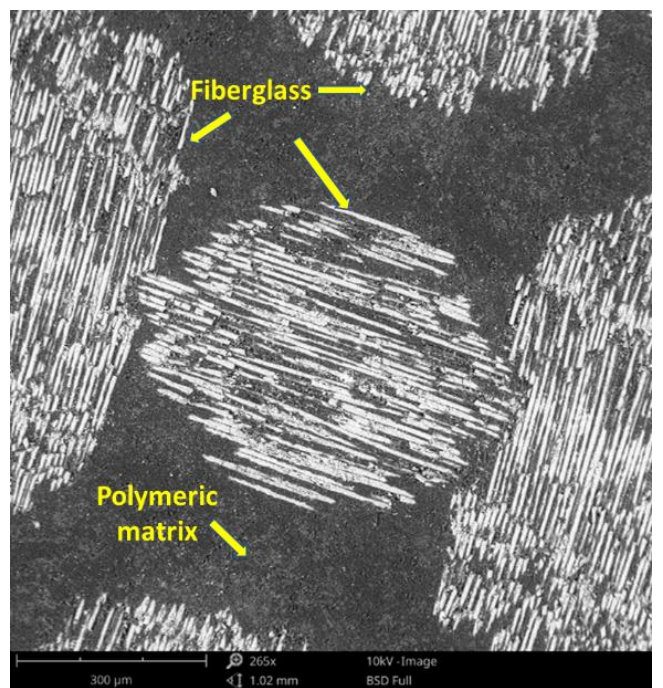

(a)

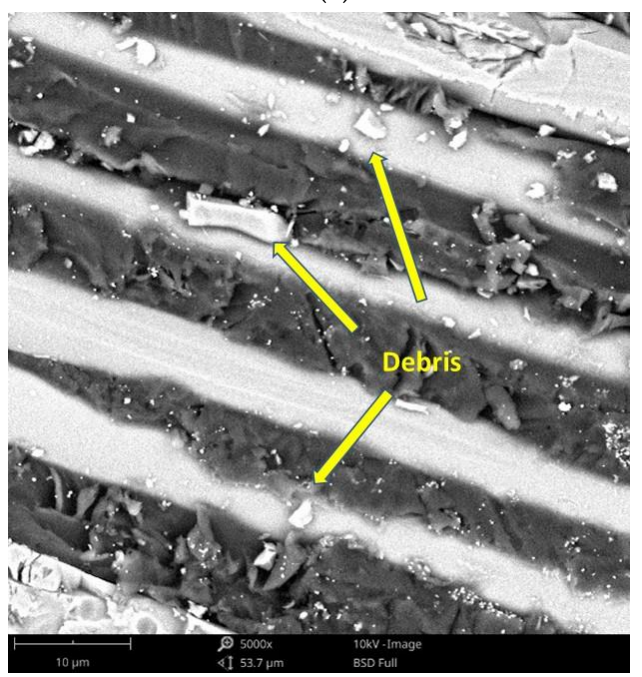

(c)

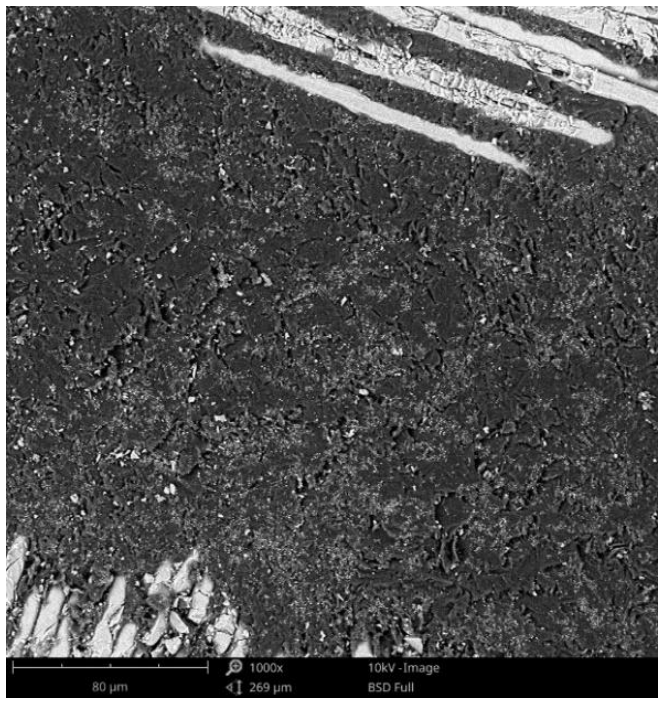

(e)

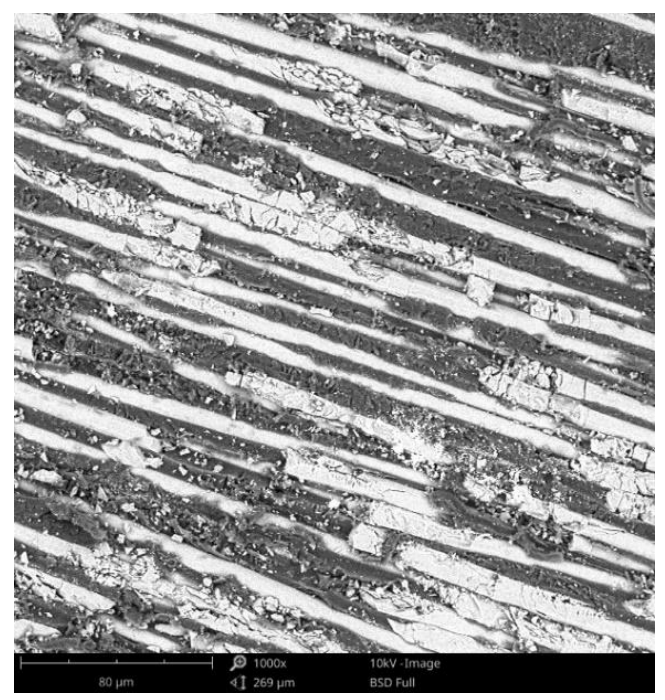

(b)

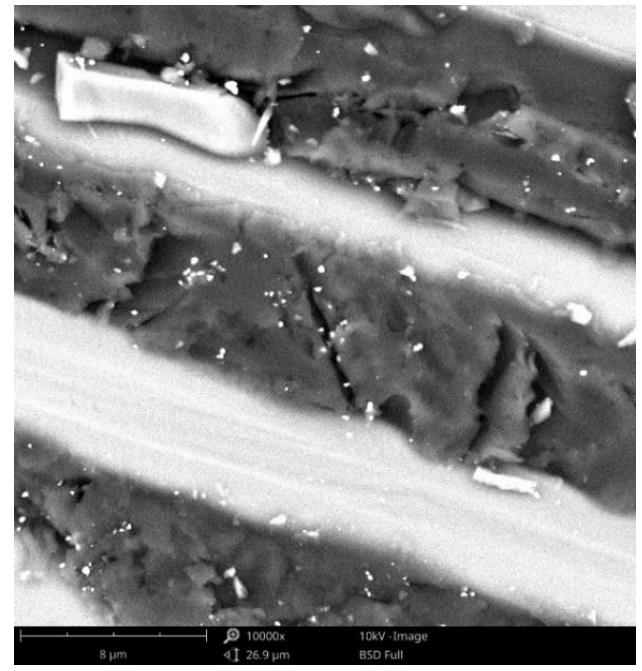

(d)

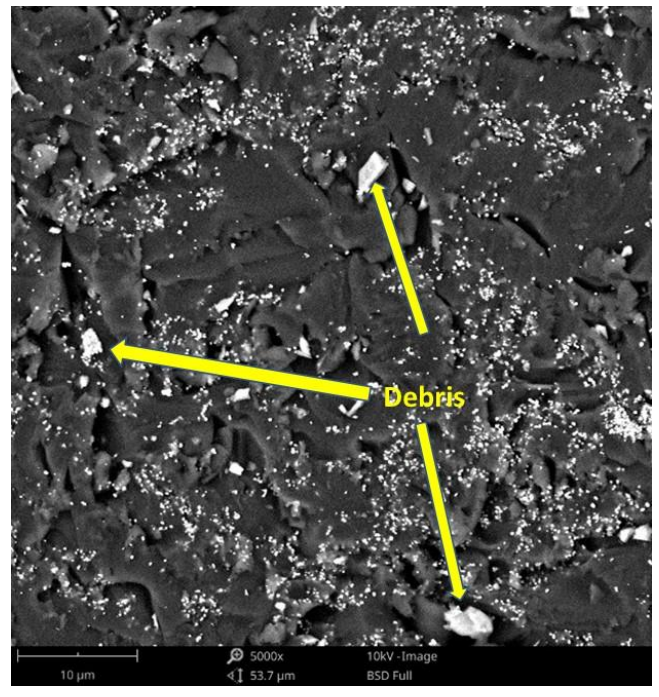

(f)

Figure 3. SEM images of C2 sample surfaces: (a) fiberglass at $265 \times$; (b) fiberglass at $1000 \times$; (c) fiberglass at $5000 \times$; (d) fiberglass at $10,000 \times$; (e) polymeric matrix at $1000 \times ;($ f) polymeric matrix at $5000 \times$. 
Regarding material C1 (Figure 2), it can be observed that the reinforcing elements made of fiberglass appear to have a lower density compared to material C2 (Figure 3).

In the SEM images of the material surfaces in Figures 2 and 3, small fragments (debris) obtained following the milling process of the resin materials can be observed in both the reinforcing material (fiberglass) and the base material (polymeric matrix). The polymeric matrix of both resin materials present porosities of various shapes and sizes.

\subsubsection{Chemical Composition}

The elemental composition of the materials used in this study, obtained using EDS in points depending on the phases/materials identified, is found in Table 3, while Figure 4 shows the SEM images in which the areas where the chemical composition was investigated are marked, alongside with the EDS spectra resulting for both $\mathrm{C} 1$ and $\mathrm{C} 2$ samples.

Table 3. Elemental composition of the samples obtained by EDS.

\begin{tabular}{cccccccccccc}
\hline \multirow{2}{*}{ Sample } & \multirow{2}{*}{ Spot } & \multicolumn{10}{c}{ Element (wt.\%) } \\
\cline { 2 - 13 } & & $\mathbf{O}$ & $\mathbf{C}$ & $\mathbf{S i}$ & $\mathbf{C a}$ & $\mathbf{A l}$ & $\mathbf{N a}$ & $\mathbf{M g}$ & $\mathbf{T i}$ & $\mathbf{C l}$ & $\mathbf{S}$ \\
\hline \multirow{2}{*}{$\mathrm{C} 1$} & 1 & 44.54 & 31.12 & 11.97 & 6.7 & 4.67 & 0.43 & 0.33 & 0.24 & - & - \\
& 2 & 25.03 & 69.89 & 1.52 & 1.09 & 0.62 & - & - & 1.63 & 0.22 & \\
\hline \multirow{2}{*}{$\mathrm{C} 2$} & 1 & 44.02 & 21.82 & 17.56 & 10.09 & 5.9 & - & 0.3 & - & - & 0.31 \\
& 2 & 27.05 & 55.59 & 3.43 & 7.69 & 1.11 & - & - & 2.73 & 0.1 & 2.29 \\
\hline
\end{tabular}

\subsection{Immersion Assay in Artificial Saliva}

The evolution of the samples' mass within the established time intervals $(3,7,14$ and 21 days) can be found in Table 4 for the samples tested in artificial saliva with different $\mathrm{pH}$ values. All the obtained results are also graphically represented in Figure 5.

Table 4. Mass evolution of the C1 and C2 samples after immersion in artificial saliva.

\begin{tabular}{cccccc}
\hline \multirow{2}{*}{$\begin{array}{c}\text { Carter Brugirard SA } \\
\text { pH }\end{array}$} & Material & \multicolumn{3}{c}{ Mass Evolution (mg) } \\
\cline { 3 - 6 } & & Day 3 & Day 7 & Day 14 & Day 21 \\
\hline \multirow{2}{*}{$\mathrm{pH}=7.6$} & $\mathrm{C} 1$ & $-0.72( \pm 0.01)$ & $-0.18( \pm 0.01)$ & $0.51( \pm 0.01)$ & $1.65( \pm 0.02)$ \\
& $\mathrm{C} 2$ & $-0.99( \pm 0.02)$ & $-0.34( \pm 0.01)$ & $0.54( \pm 0.01)$ & $1.54( \pm 0.01)$ \\
\hline \multirow{2}{*}{$\mathrm{pH}=5.7$} & $\mathrm{C} 1$ & $-0.73( \pm 0.01)$ & $-0.27( \pm 0.01)$ & $0.59( \pm 0.02)$ & $1.72( \pm 0.02)$ \\
& $\mathrm{C} 2$ & $-1.11( \pm 0.02)$ & $-0.40( \pm 0.01)$ & $0.59( \pm 0.01)$ & $1.82( \pm 0.02)$ \\
\hline \multirow{2}{*}{ varying pH from } & $\mathrm{C} 1$ & $-0.86( \pm 0.02)$ & $-0.46( \pm 0.01)$ & $0.30( \pm 0.02)$ & $0.98( \pm 0.02)$ \\
5.7 to 3 & $\mathrm{C} 2$ & $-1.05( \pm 0.02)$ & $-0.68( \pm 0.02)$ & $0.18( \pm 0.01)$ & $1.10( \pm 0.01)$ \\
\hline
\end{tabular}

Following the immersion tests, the mass of both studied composite materials shows a similar variation regardless of the $\mathrm{pH}$ of the artificial saliva used as a testing medium. Thus, after 3 and 7 days, the mass of the samples tends to decrease and starting with the 14th day it starts to increase, reaching its highest value after 21 days. However, it should be mentioned that the variation of the registered mass is not very large, being in the range of $-0.18( \pm 0.01)-1.82( \pm 0.02) \mathrm{mg}$.

\subsection{Surface Morphology after Immersion Tests in Artificial Saliva}

For a detailed analysis of the samples' surfaces after immersion tests, they were investigated by SEM. For these investigations, samples were selected after 3 and 21 days of immersion, for all $\mathrm{pH}$ types, and the images obtained are presented in Figures $6-8$ for $\mathrm{C} 1$, and Figures 9-11 for $\mathrm{C} 2$. This selection considered the maximum mass variations of the samples following the immersion tests. 

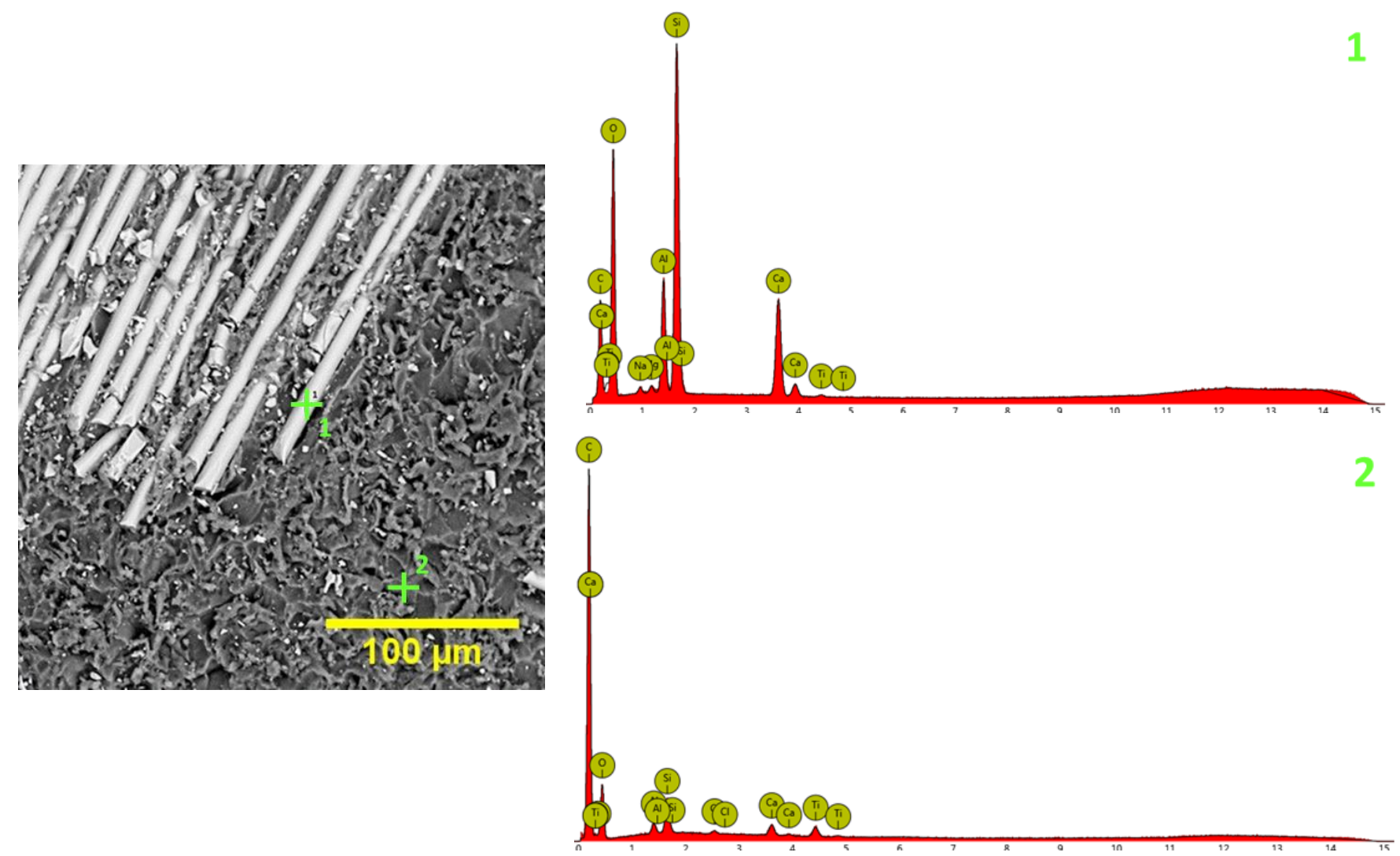

(a)

(b)
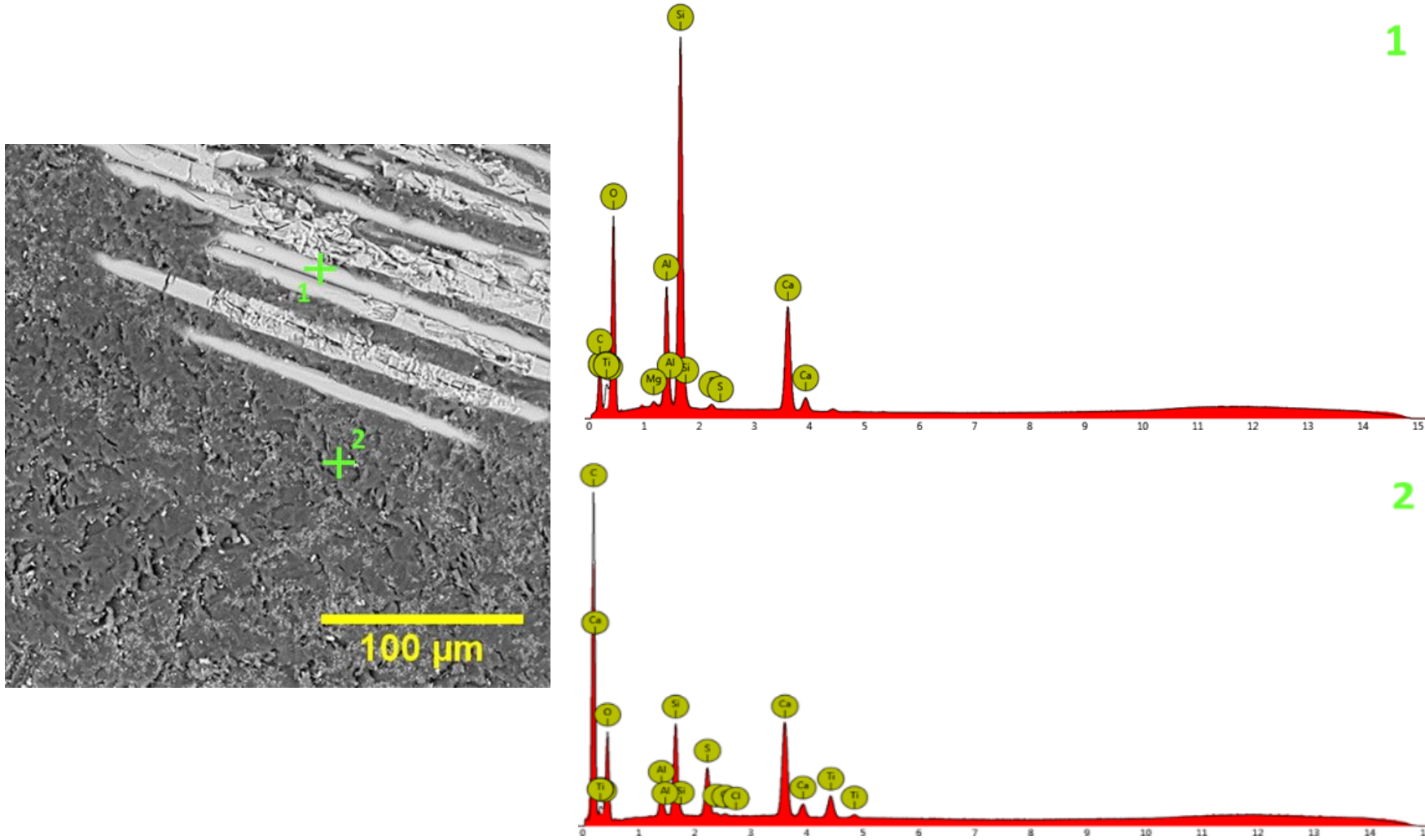

(c)

(d)

Figure 4. SEM images marking the points where the chemical composition was investigated (a,c) and the resulting EDS spectra $(\mathbf{b}, \mathbf{d})$. 


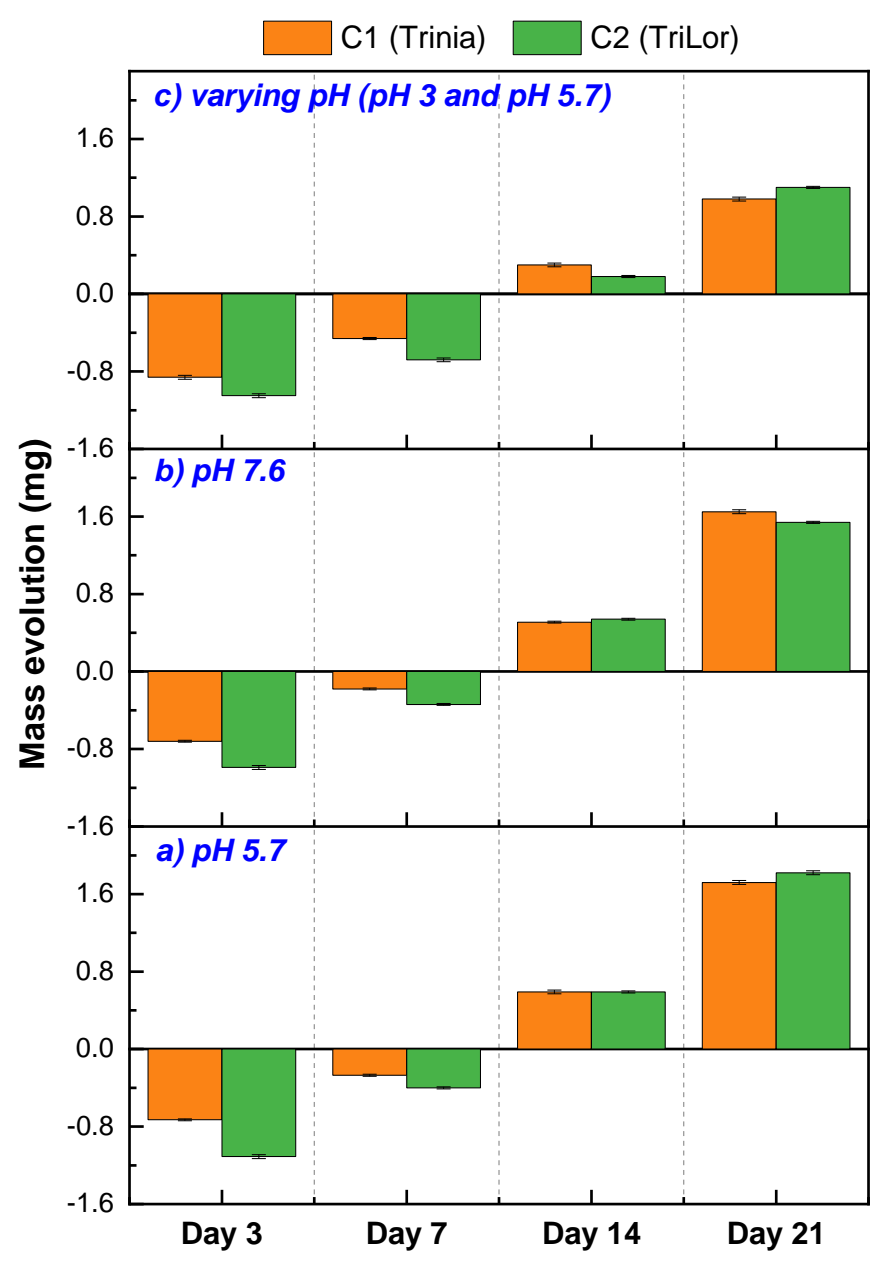

Figure 5. Evolution of the samples mass in artificial saliva: (a) of $\mathrm{pH}$ 5.7; (b) of $\mathrm{pH} 7.6$; (c) of varied $\mathrm{pH}(5.7-3)$.

(a)
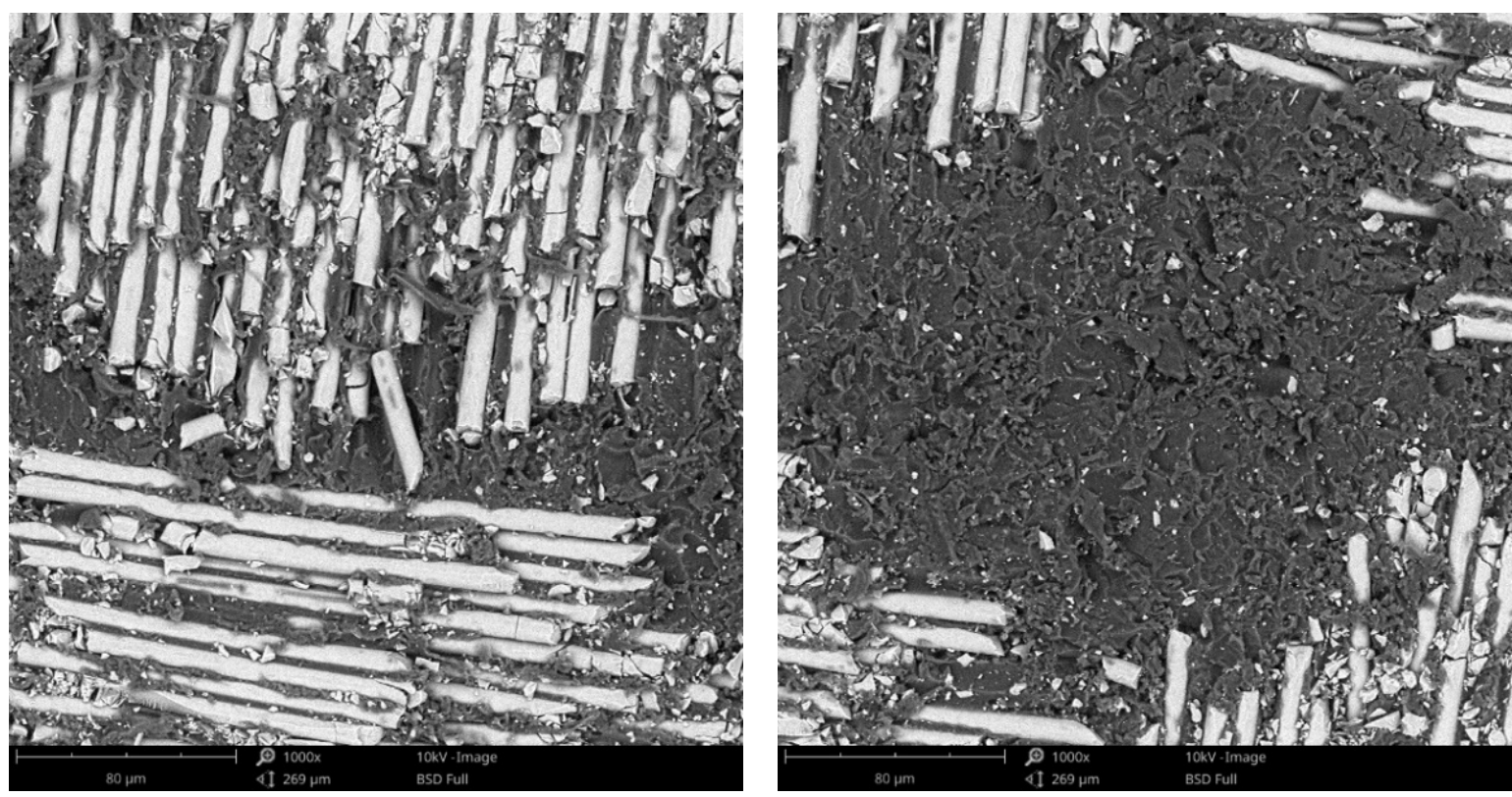

Figure 6. Cont. 
(b)
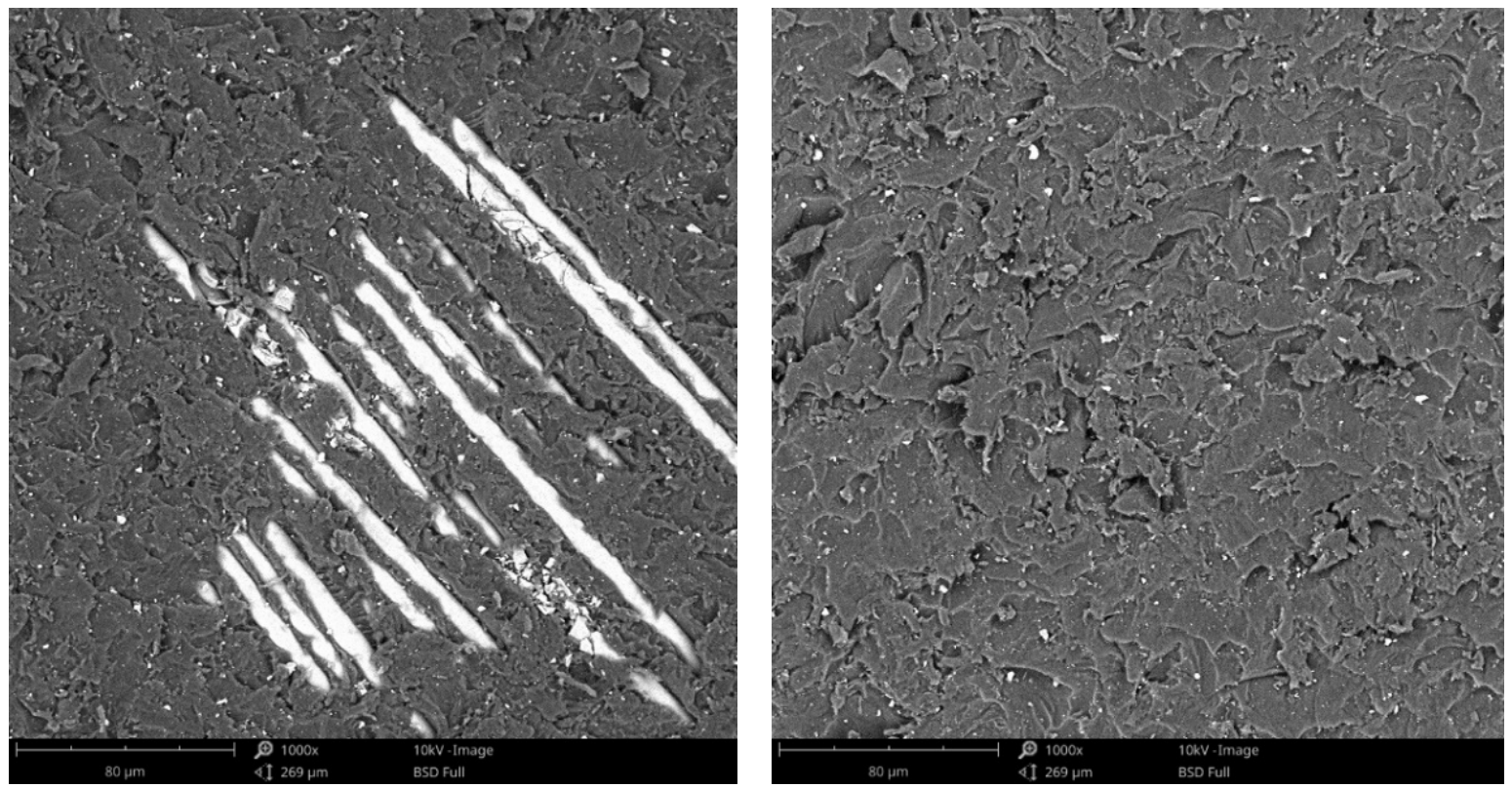

Figure 6. SEM images of the $\mathrm{C} 1$ sample surface after immersion tests at (a) 3 days and (b) 21 days in artificial saliva with pH $5.7(1000 \times)$.

(a)
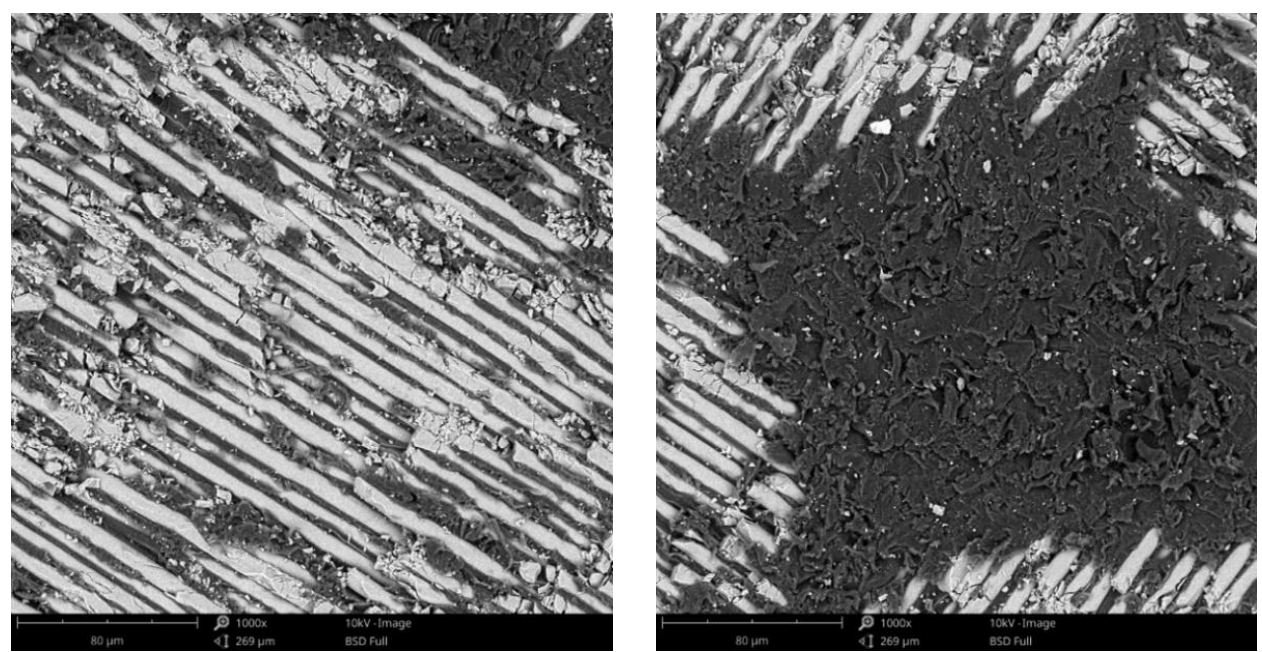

(b)
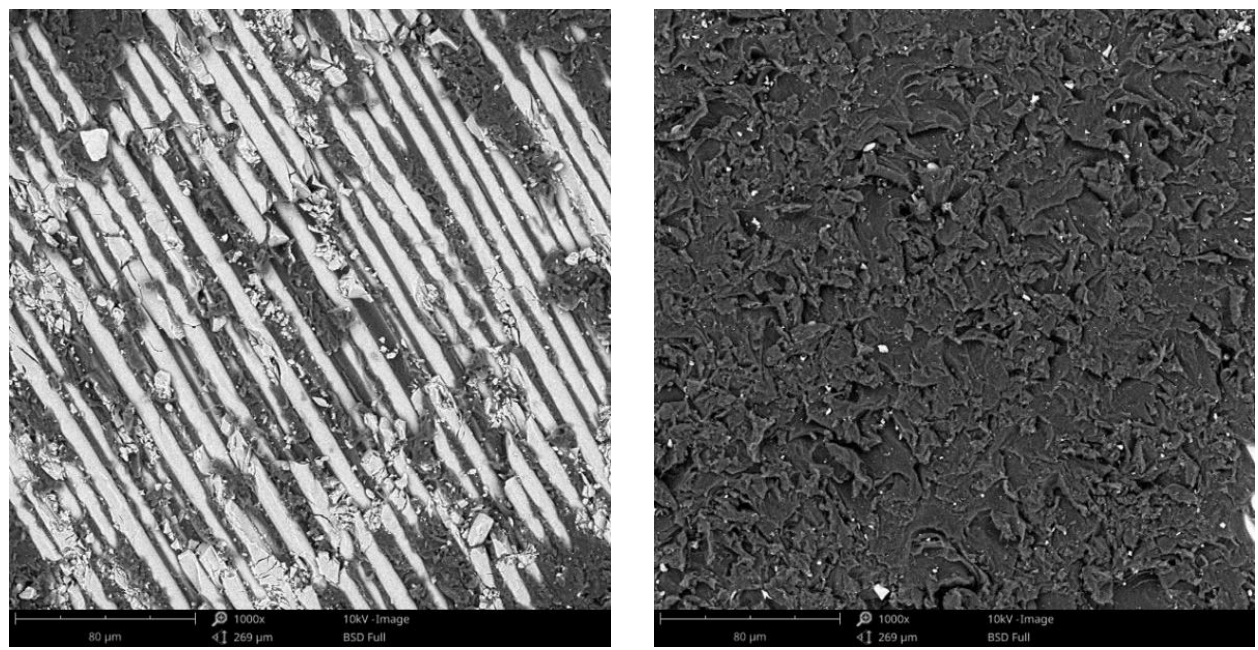

Figure 7. SEM images of the $\mathrm{C} 1$ sample surface after immersion tests at (a) 3 days and (b) 21 days in artificial saliva with $\mathrm{pH} 7.6(1000 \times)$. 
(a)

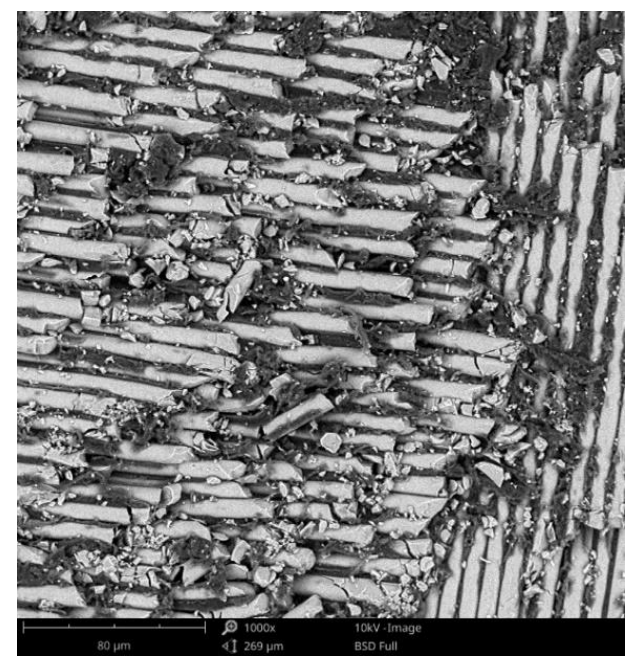

(b)

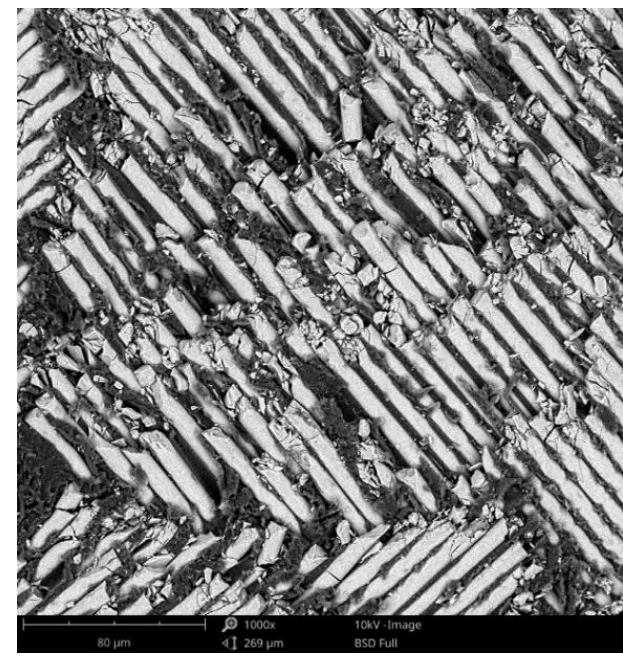

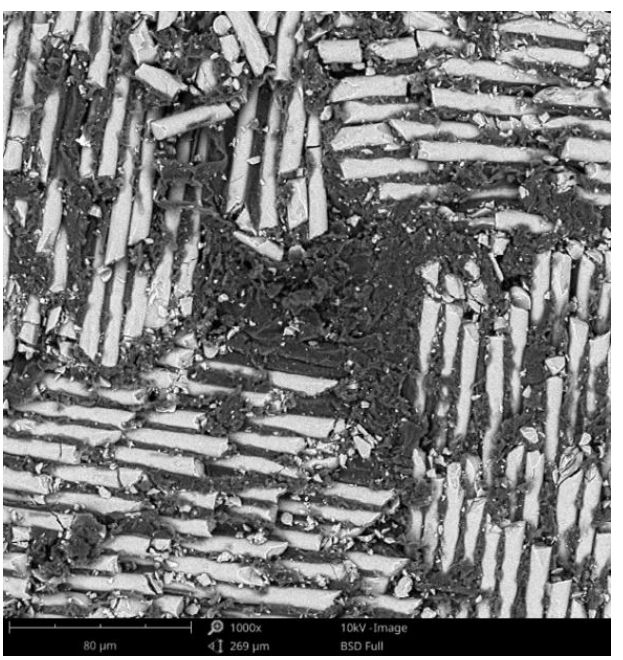

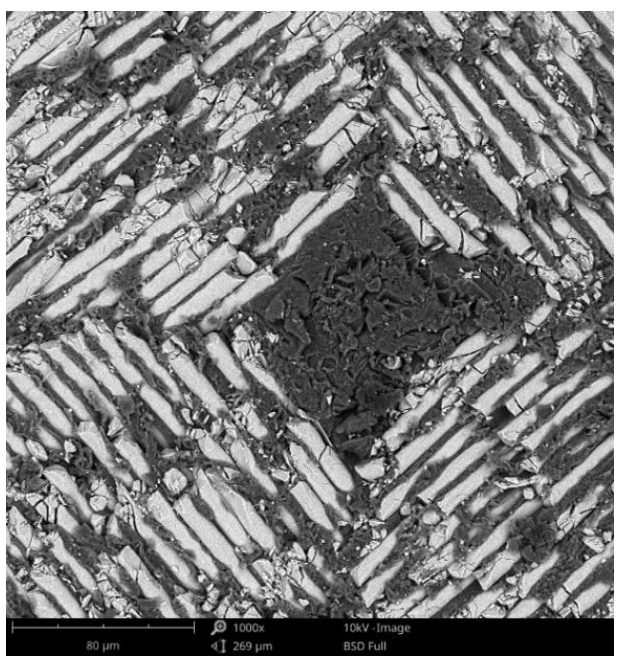

Figure 8. SEM images of the $\mathrm{C} 1$ sample surface after immersion tests at (a) 3 days and (b) 21 days in artificial saliva with varying $\mathrm{pH}(1000 \times)$.

(a)

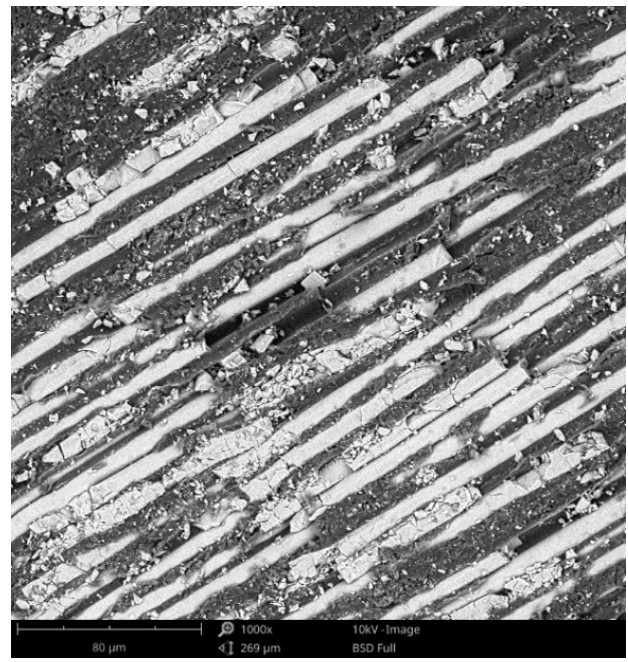

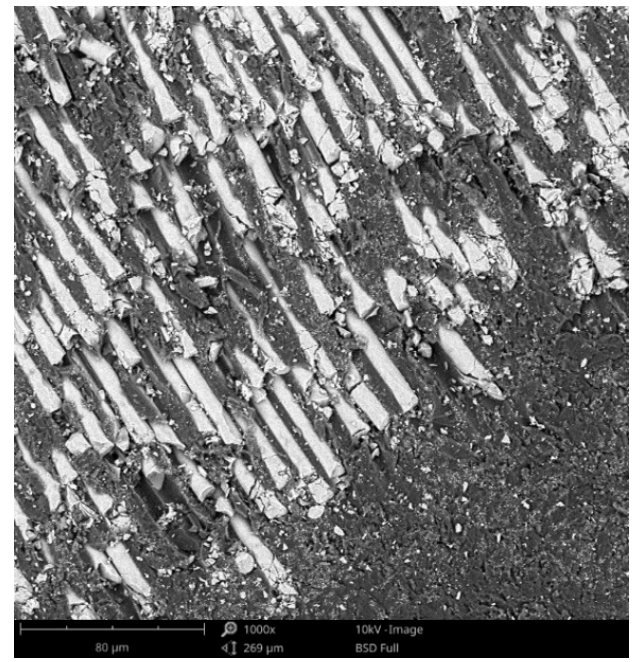

Figure 9. Cont. 
(b)
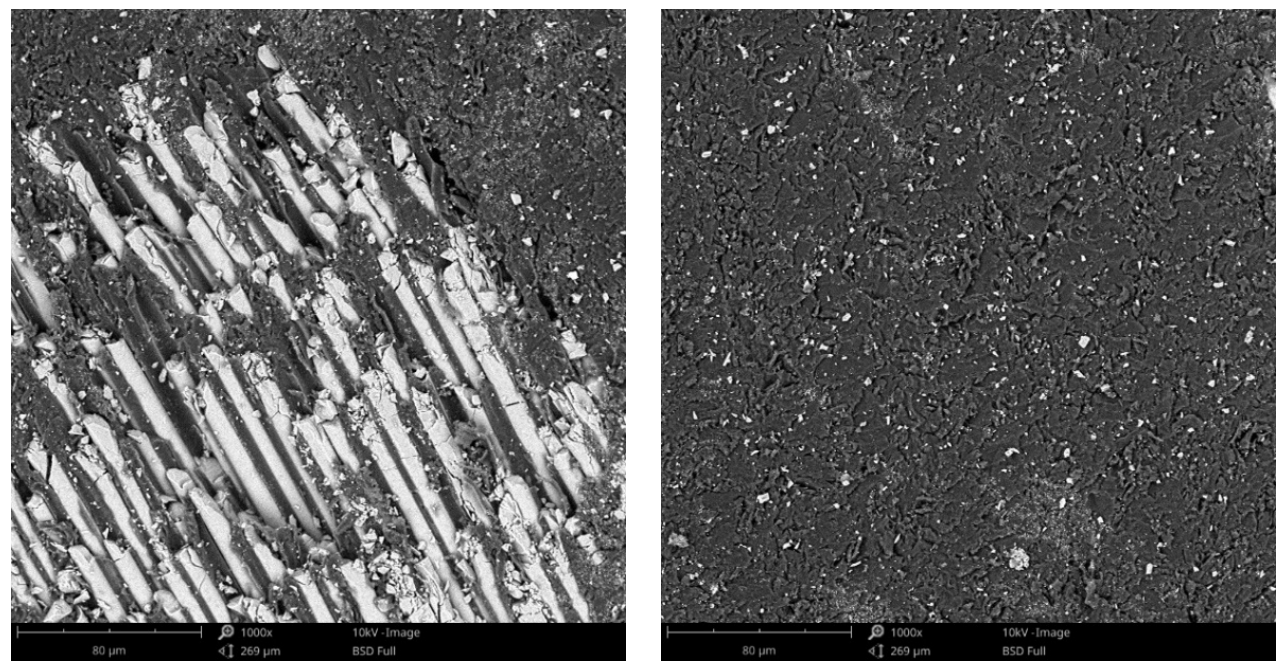

Figure 9. SEM images of the $\mathrm{C} 2$ sample surface after immersion tests at (a) 3 days and (b) 21 days in artificial saliva with $\mathrm{pH} 5.7(1000 \times)$.

(a)

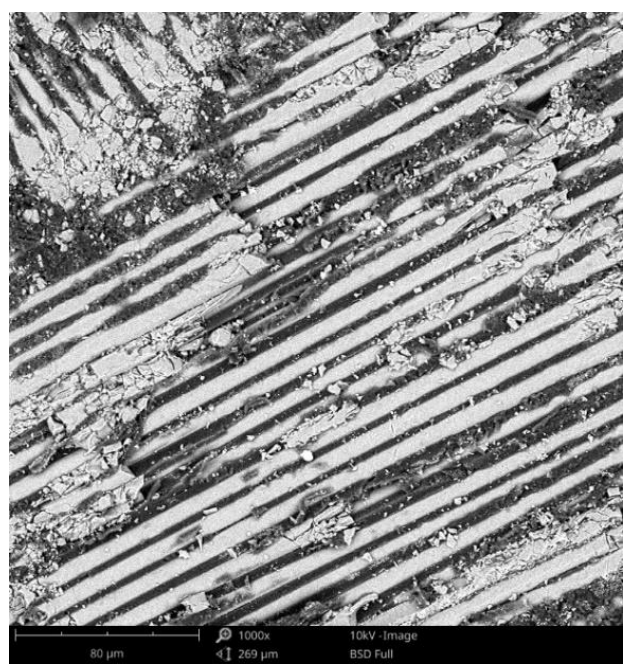

(b)
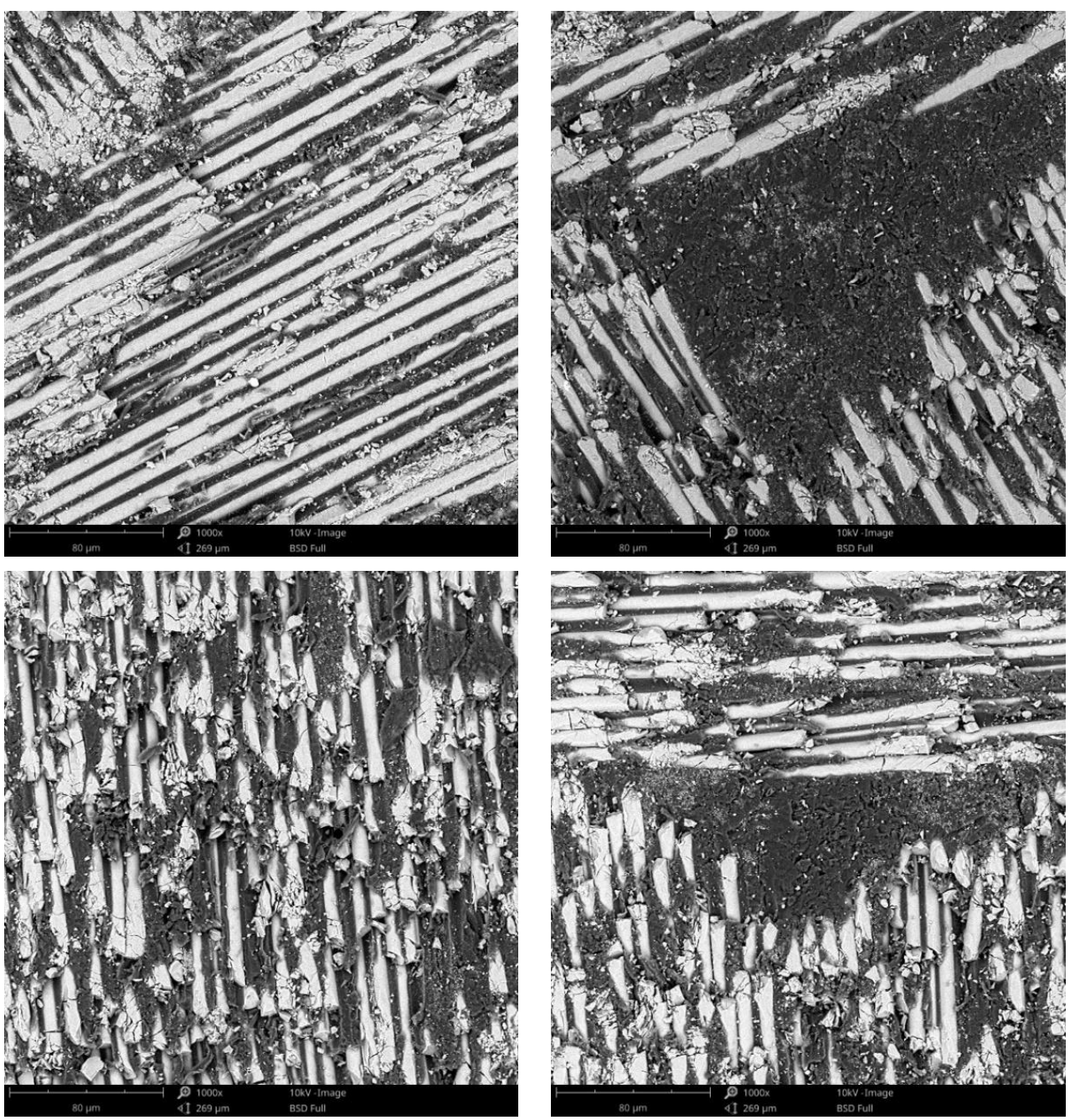

Figure 10. SEM images of the $\mathrm{C} 2$ sample surface after immersion tests at (a) 3 days and (b) 21 days in artificial saliva with $\mathrm{pH} 7.6(1000 \times)$. 
(a)

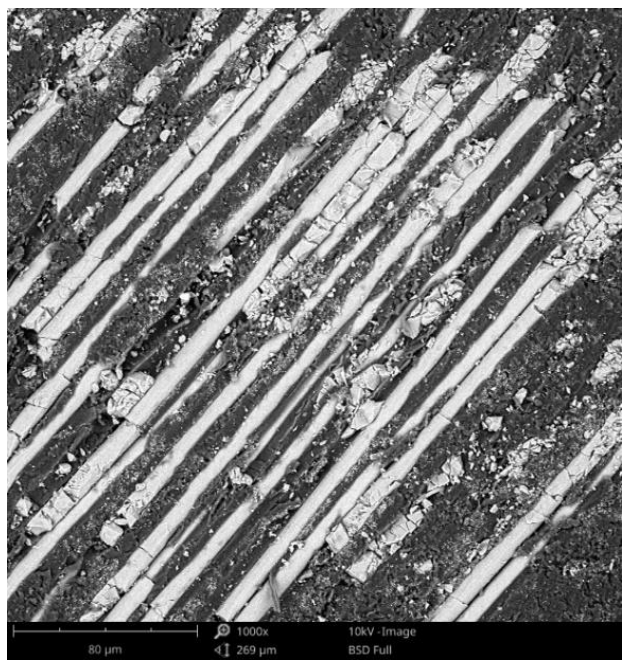

(b)

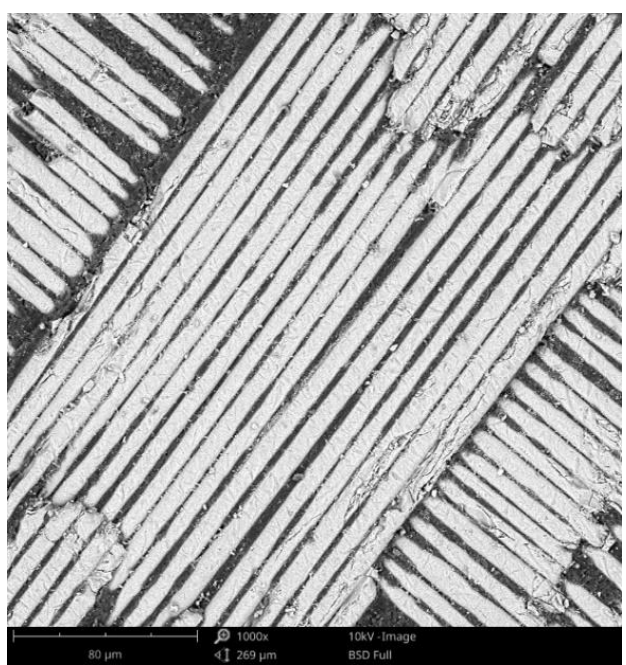

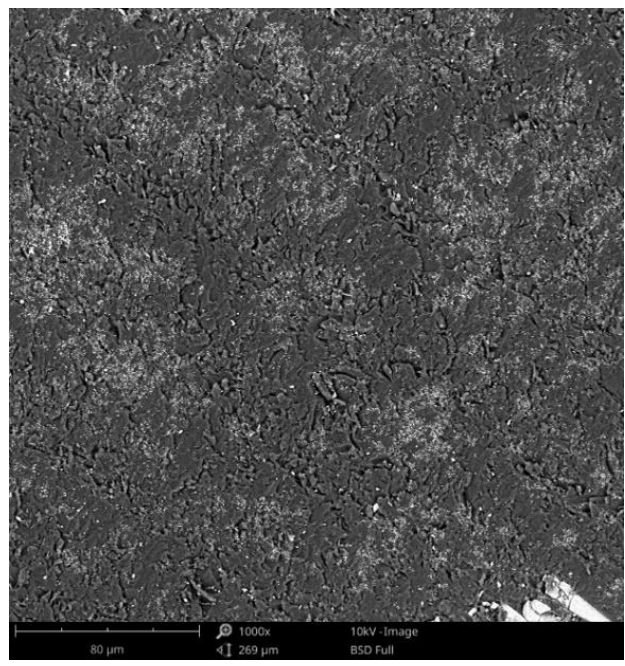

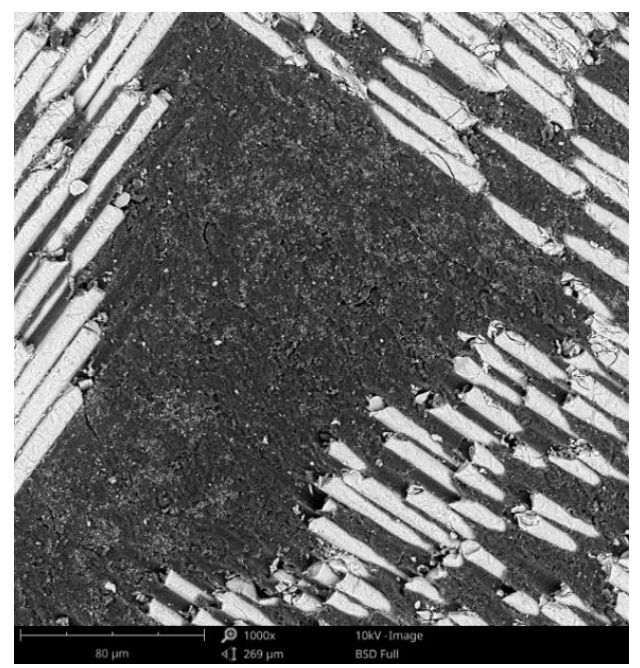

Figure 11. SEM images of the $C 2$ sample surface after immersion tests at (a) 3 days and (b) 21 days in artificial saliva with varying $\mathrm{pH}(1000 \times)$.

After a careful analysis of SEM images of the investigated surfaces of both composite materials before and after the immersion tests (studying both components, namely resin matrix and fiberglass), it can be stated that there are no notable differences and that the immersion tests did not induce morphological changes in any of the two composite materials regardless of the $\mathrm{pH}$ value used or the immersion period.

\section{Discussion}

CAD/CAM technology eliminates dimensional changes during the laboratory manufacturing process. In order to achieve a high modulus of resilience and great flexural strength, composite resin-based materials were manufactured using this technology, with filler particles bonded to resin matrix [32].

In order to obtain optimal compatibility of filler particles with resin phase, various surface modifications techniques of filler particles have been suggested [33].

A reinforcement of resin materials with glass fibers significantly improves their mechanical and functional characteristics, as well as and biological tolerance, making them a viable solution for the prosthetic rehabilitation of patients [34].

Fiber-reinforced composite (FRC) dental materials have been specifically studied and advanced for over 25 years [35,36]. In FRC dental materials, the fibers are included particularly for their high specific modulus (stiffness and weight), as well as their specific strength and weight $[7,37]$. 
The surface morphology obtained by SEM of the two fiber-reinforced resin materials used in the study showed that Trinia ${ }^{\mathrm{TM}}$ appears to have a lower density of reinforcing elements made of fiberglass, when compared to TriLor. This statement is closely correlated with the data from the literature but also the technical data provided by the manufacturer, which states that Trinia ${ }^{\mathrm{TM}}$ (Bicon Dental Implants) has approximately 55\% solid fiberglass [38], while for Trilor (Bioloren), the glass fiber is found in approximately $75 \%$ of the total volume $[35,39,40]$.

With a flexural strength of $393 \mathrm{Mpa}$, Trinia's application can be expanded into posterior regions of the mouth, with use in frameworks of fixed dental restorations and implant prostheses [41]. Trinia presents outstanding properties besides a high flexural strength, such as a flexural modulus of elasticity comparable to dentin and a high level of resilience. Trinia has been demonstrated to simulate the performance of Sharpey's fibers due to its so-called buffering feature. Another feature of this FRC is the very low water adsorption, namely $0.03 \%$ [20].

A common concern regarding dental materials is their hydrolytic degradation due to the continuous exposure to the aqueous environment of the oral cavity [42].

Water sorption is realized by two means: adsorption and absorption. Adsorption is the attachment of molecules of a liquid or gas on the resin surface and absorption happens by penetration of liquid or gas within the mass of the composite resins [43]. Water sorption and hygroscopic expansion are among the physical properties of the composites. Water sorption may adversely affect the quality of the composite, thereby changing its efficiency as a restorative material [44].

Because water serves as a plasticizer, when absorbed by resins, it may cause discoloration, increased solubility, dimensional expansion and may affect their properties such as fatigue limit, transverse strength, and hardness. In addition, water sorption causes three-dimensional expansion, and this can lead to dimensional instability of the prostheses framework [45].

The oral environment can interfere with the water sorption of composite resins, due to its $\mathrm{pH}$ variation, either through acidic foods or organic acids (lactic and acetic acid) [43] or, in case of patients suffering from GERD, through the regurgitation of gastric juices into the oral cavity [46].

Water absorption and dimensional change of CAD/CAM polymers may be affected by variations in the composition aiming to improve the mechanical properties of these polymers. This phenomenon happens due to the fluid absorption in the polymer matrix, the highest moisture absorption generally occurring within the first few days, following a tendency to stabilize $[47,48]$.

Based on the SEM images obtained after the immersion assay in our study, the weight loss registered in the first two monitoring periods ( 3 and 7 days) may be due to the loss on the surface of some residues/debris resulting from the milling process and the weight gain of the samples in the last periods of monitoring the samples' masses (14 and 21 days) may be due to the infiltration of artificial saliva into the pores of the polymeric matrix and the crystallization of the salts inside them after drying. Both processes mentioned take place simultaneously but the first is predominant in the first part of the tests, while the second is during the second part.

Suzaki et al. [18] tested the water absorption of Trinia, a fiber-reinforced composite (everX posterior, GC) and a conventional composite (Beauti core flow paste, SHOFU) by immersing the samples in water at $37 \circ \mathrm{C}$ for 7 days. The lowest water absorption $\left(4.7 \pm 1.9 \mathrm{~g} / \mathrm{mm}^{3}\right)$ was found in Trinia out of all three materials. However, flexural strength significantly decreased from $24 \mathrm{~h}$ to 1 week, as opposed to the FS in everX posterior and Beauti core flow paste immersion groups. In Trinia and everX posterior groups, all specimens demonstrated incomplete fracture after the three-point bending test while in Beauti core flow paste group, all specimens demonstrated complete fracture. A smaller elastic modulus after 1 week was found, without any significant difference between the samples. 
The highest impact on solubility found by Liebermann et al. [47] in their study on different computer-aided design and computer-aided manufacturing (CAD/CAM) polymers was for storage in physiological saliva. This result is probably due to the complex mixture of organic and inorganic components of natural saliva, which lead to a higher solubility rate than artificial saliva and especially $\mathrm{NaCl}$ and distilled water.

Gusmão et al. [43] studied the water sorption of nine specimens of nanoparticle, microhybrid, and nanohybrid composite resins stored in artificial saliva with $\mathrm{pH} 7.0$ (control) and varying $\mathrm{pH}$ (4.3-7.0) for the test group. Weight gain for all the resins at all-time intervals was observed and the authors concluded that the degree of sorption is dependent upon storage time and composite chemical composition and was affected by the medium $\mathrm{pH}$.

It is important to note that the use of artificial saliva simulates only the hydrolytic degradation of composite [49]. The rate of hydrolytic degradation depends on environmental factors (temperature, $\mathrm{pH}$ ), storage time, and polymer properties, including resin matrix/filler particles proportion [47].

In his dissertation thesis, Abdallah [50] concludes that full-arch implant prostheses with Trinia framework are a viable option for fixed implant rehabilitation demonstrating damping capacity, adequate failure load values, and easy repairability.

Not many studies regarding the behavior of Trilor's mechanical properties after immersion tests were found in the literature. In Ruschel et al. study [51], 10 prefabricated glass fiber posts (Exacto \#3; Angelus, Londrina, PR, Brazil), 10 diagonally and 10 vertically CAD/CAM milled posts (Trilor, Bioloren) were evaluated using laser confocal microscopy and a parallel fiber distribution of glass fibers was observed for the prefabricated post, while the diagonally milled post presented multi-direction fiber distribution and the vertically milled one showed transversal parallel fiber distribution. The posts were not previously aged and authors concluded that prefabricated glass fiber posts presented higher flexural strength and modulus, as well as higher superficial roughness, in comparison to Trilor CAD/CAM milled posts.

After Scribante [37] and Sfondrini [52], the limiting clinical use of FRCs, despite the numerous studies carried out in vitro, is represented by the absence of long-term clinical studies regarding the efficiency of these dental materials.

Although Musanje concluded that the best method of simulating oral conditions in vitro is the use of artificial saliva at $37^{\circ} \mathrm{C}$ [53] and aging the composites in artificial saliva is considered to simulate the clinical situation [49], this type of medium does not replicate the properties and the mechanical and chemical effects that physiological saliva has on composite materials. The immersion tests performed in our study were limited by the difficulty to mimic the harsh oral environment conditions, including temperature variation and acids present in food.

Laboratory tests provide only some evidence of reliable values, and supplementary clinical studies are required to validate the obtained results and to improve the quality and the properties of FRC dental materials [47].

In advance of long-term clinical trials, in vitro testing of any new biomaterial is required to initially validate the manufacturer's claims and provide initial predictors for restoration success [54]. For the advancement in the dental materials used for the achievement of prosthetic restorations, research for superior biomaterials should continue [5,55].

\section{Conclusions}

The results of our study reveal the necessity for the preclinical evaluation of novel metal-free biomaterials to be able to predict their clinical performance.

The immersion assay performed in artificial saliva at different $\mathrm{pH}$ levels suggested that, irrespective of the $\mathrm{pH}$ value of the medium, the two investigated CAD/CAM milled FRCs (Trinia ${ }^{\mathrm{TM}}$, Trilor) present similar trends in terms of mass variation after 21 days of immersion, suggesting their stability when in contact with artificial saliva, an aspect which was also highlighted by SEM analysis performed on the immersed surfaces. 
Within the limitations of this in vitro study, it can be concluded that the novel composite biomaterials can be a proper alternative for metal alloys used for prosthetic frameworks and represent a viable option of dental materials for the oral rehabilitation of patients suffering from GERD.

Author Contributions: Conceptualization, F.B. and C.M.C.; methodology, F.B. and E.S.B.; validation, E.U., D.M.V. and S.M.B.; formal analysis, M.S.; investigation, E.U. and D.M.V.; resources, S.M.B. and A.T.; data curation, E.U. and D.M.V.; writing — original draft preparation, C.M.C. and F.B.; writingreview and editing, E.U., D.M.V. and E.S.B.; visualization, F.B.; supervision, C.M.C., S.M.B. and A.T.; project administration, F.B. and C.M.C. All authors have read and agreed to the published version of the manuscript.

Funding: This research received no external funding.

Institutional Review Board Statement: Not applicable.

Informed Consent Statement: Not applicable.

Data Availability Statement: Data sharing is not applicable to this article.

Acknowledgments: The composite samples used in the study were manufactured and provided by Dr. Fischer Dental, Bucharest, Romania.

Conflicts of Interest: The authors declare no conflict of interest.

\section{References}

1. Ngo, Tri-Dung. Introduction to Composite Materials. In Composite and Nanocomposite Materials—From Knowledge to Industrial Applications; IntechOpen: London, UK, 2020. [CrossRef]

2. Zhou, X.; Huang, X.; Li, M.; Peng, X.; Wang, S.; Zhou, X.; Cheng, L. Development and status of resin composite as dental restorative materials. J. Appl. Polym. Sci. 2019, 136, 48180. [CrossRef]

3. Reddy, M.S.B.; Ponnamma, D.; Choudhary, R.; Sadasivuni, K.K. A Comparative Review of Natural and Synthetic Biopolymer Composite Scaffolds. Polymers 2021, 13, 1105. [CrossRef]

4. Rokaya, D.; Srimaneepong, V.; Sapkota, J.; Qin, J.; Siraleartmukul, K.; Siriwongrungson, V. Polymeric materials and films in dentistry: An overview. J. Adv. Res. 2018, 14, 25-34. [CrossRef]

5. Patel, E.; Choonara, Y.E.; Pillay, V. Dental biomaterials: Challenges in the translation from lab to patient. S. Afr. Dent. J. 2020, 75, 16-28. [CrossRef]

6. Kabbej, M.; Guillard, V.; Angellier-Coussy, H.; Wolf, C.; Gontard, N.; Gaucel, S. 3D Modelling of Mass Transfer into Bio-Composite. Polymers 2021, 13, 2257. [CrossRef] [PubMed]

7. Rajak, D.K.; Pagar, D.D.; Menezes, P.M.; Linul, E. Fiber-Reinforced Polymer Composites: Manufacturing, Properties, and Applications-Review. Polymers 2019, 11, 1667. [CrossRef]

8. Subhan, M.A.; Choudhury, K.P.; Neogi, N. Advances with Molecular Nanomaterials in Industrial Manufacturing Applications. Nanomanufacturing 2021, 1, 75-97. [CrossRef]

9. de Oliveira, A.D.; Augusto Gonçalves, C.B. Polymer Nanocomposites with Different Types of Nanofiller. In NanocompositesRecent Evolutions; Sivasankaran, S., Ed.; IntechOpen: London, UK, 2018. [CrossRef]

10. Prasad, K.; Bazaka, O.; Chua, M.; Rochford, M.; Fedrick, L.; Spoor, J.; Symes, R.; Tieppo, M.; Collins, C.; Cao, A.; et al. Metallic Biomaterials: Current Challenges and Opportunities. Materials 2017, 10, 884. [CrossRef]

11. Bechir, F.; Bataga, S.M.; Ungureanu, E.; Vranceanu, D.M.; Pacurar, M.; Bechir, E.S.; Cotrut, C.M. Experimental Study Regarding the Behavior at Different $\mathrm{pH}$ of Two Types of Co-Cr Alloys Used for Prosthetic Restorations. Materials 2021, 14, 4635. [CrossRef]

12. Poggio, C.E.; Ercoli, C.; Rispoli, L.; Maiorana, C.; Esposito, M. Metal-free materials for fixed prosthodontic restorations. Cochrane Database Syst. Rev. 2017, 12, CD009606. [CrossRef]

13. García-Engra, G.; Fernandez-Estevan, L.; Casas-Terrón, J.; Fons-Font, A.; Castelo-Baz, P.; Agustín-Panadero, R.; Román-Rodriguez, J.L. Fracture Resistance of New Metal-Free Materials Used for CAD-CAM Fabrication of Partial Posterior Restorations. Medicina 2020, 56, 132. [CrossRef] [PubMed]

14. Skorulska, A.; Piszko, P.; Rybak, Z.; Szymonowicz, M.; Dobrzyński, M. Review on Polymer, Ceramic and Composite Materials for CAD/CAM Indirect Restorations in Dentistry-Application, Mechanical Characteristics and Comparison. Materials 2021, 14, 1592. [CrossRef]

15. Tharani Kumar, S.; Prasanna Devi, S.; Krithika, C.; Raghavan, R.N. Review of Metallic Biomaterials in Dental Applications. J. Pharm. Bioallied Sci. 2020, 12, S14-S19. [CrossRef]

16. Sinha, N. Shear Bond Strength Characteristics on Surface Treatment Modalities of CAD-CAM Resin Based Core Materials. Master's Thesis, Marquette University, Milwaukee, WI, USA, 2021. 
17. Passaretti, A.; Petroni, G.; Miracolo, G.; Savoia, V.; Perpetuini, A.; Cicconetti, A. Metal free, full arch, fixed prosthesis for edentulous mandible rehabilitation on four implants. J Prosthodont. Res. 2018, 62, 264-267. [CrossRef] [PubMed]

18. Suzaki, N.; Yamaguchi, S.; Hirose, N.; Tanaka, R.; Takahashi, Y.; Imazato, S.; Hayashi, M. Evaluation of physical properties of fiber-reinforced composite resin. Dent. Mater. 2020, 36, 987-996. [CrossRef] [PubMed]

19. Available online: https://www.shofu.com/wp-content/uploads/CAD-CAM-Article-US-Inside-Dental-Technology.pdf (accessed on 11 October 2021).

20. Ewers, R.; Perpetuini, P.; Morgan, J.V.; Marincola, M.; Wu, R.; Seemann, R. TRINIA ${ }^{\text {TM}_{-}}$Metal-free restorations. Implants 2017, $1,22-27$.

21. Available online: https://www.trinia.com/ (accessed on 10 October 2021).

22. Available online: https://preat.com/attachment_systems/trilor-high-performance-polymer/ (accessed on 11 October 2021).

23. Available online: www.bioloren.com (accessed on 10 October 2021).

24. Available online: https://bioloren.com/trilor/ (accessed on 11 October 2021).

25. Hao, Y.; Huang, X.; Zhou, X.; Li, M.; Ren, B.; Peng, X.; Cheng, L. Influence of Dental Prosthesis and Restorative Materials Interface on Oral Biofilms. Int. J. Mol. Sci. 2018, 19, 3157. [CrossRef]

26. Lee, Y.-H.; Chung, S.W.; Auh, Q.-S.; Hong, S.-J.; Lee, Y.-A.; Jung, J.; Lee, G.-J.; Park, H.J.; Shin, S.-I.; Hong, J.-Y. Progress in Oral Microbiome Related to Oral and Systemic Diseases: An Update. Diagnostics 2021, 11, 1283. [CrossRef]

27. Clarrett, D.M.; Hachem, C. Gastroesophageal Reflux Disease (GERD). Mo. Med. 2018, 115, $214-218$.

28. Watanabe, M.; Nakatani, E.; Yoshikawa, H.; Kanno, T.; Nariai, Y.; Yoshino, A.; Vieth, M.; Kinoshita, Y.; Sekine, J. Oral soft tissue disorders are associated with gastroesophageal reflux disease: Retrospective study. BMC Gastroenterol. 2017, 92. [CrossRef]

29. Kreth, J.; Merritt, J.; Pfeifer, C.S.; Khajotia, S.; Ferracane, J.L. Interaction between the Oral Microbiome and Dental Composite Biomaterials: Where We Are and Where We Should Go. J. Dent. Res. 2020, 99, 1140-1149. [CrossRef] [PubMed]

30. Saramet, V.; Melescanu-Imre, M.; Tâncu, A.M.C.; Albu, C.C.; Ripszky-Totan, A.; Pantea, M. Molecular Interactions between Saliva and Dental Composites Resins: A Way Forward. Materials 2021, 14, 2537. [CrossRef] [PubMed]

31. Vlădescu, A.; Pârâu, A.; Pană, I.; Cotruț, C.M.; Constantin, L.R.; Braic, V.; Vrânceanu, D.M. In Vitro Activity Assays of Sputtered HAp Coatings with SiC Addition in Various Simulated Biological Fluids. Coatings 2019, 9, 389. [CrossRef]

32. Porto, T.S.; Roperto, R.C.; Akkus, A.; Akkus, O.; Teich, S.; Faddoul, F.; Porto-Neto, S.T.; Campos, E.A. Effect of storage and aging conditions on the flexural strength and flexural modulus of CAD/CAM materials. Dent Mater. J. 2019, 38, 264-270. [CrossRef] [PubMed]

33. Pratap, B.; Gupta, R.K.; Bhardwaj, B.; Nag, M. Resin based restorative dental materials: Characteristics and future perspectives Jpn. Dent. Sci. Rev. 2019, 55, 126-138. [CrossRef]

34. Jovanovic, M.; Zivic, M.; Milosavljevic, M. A Potential Application of Materials Based on a Polymer and CAD/CAM Composite Resins in Prosthetic Dentistry. J. Prosthodont. Res. 2020, 65, 137-147. [CrossRef]

35. Scribante, A.; Vallittu, P.K.; Özcan, M. Fiber-Reinforced Composites for Dental Applications. BioMed Res. Int. 2018, $2018,4734986$. [CrossRef]

36. Vallittu, P.K. An overview of development and status of fiber-reinforced composites as dental and medical biomaterials. Acta Biomater. Odontol. Scand. 2018, 4, 44-55. [CrossRef]

37. Scribante, A.; Vallittu, P.K.; Özcan, M.; Lassila, L.; Gandini, P.; Sfondrini, M.F. Travel beyond Clinical Uses of Fiber Reinforced Composites (FRCs) in Dentistry: A Review of Past Employments, Present Applications, and Future Perspectives. BioMed Res. Int. 2018, 2018, 1498901. [CrossRef]

38. Eid, R.; Azzam, K.; Skienhe, H.; Ounsi, H.; Ferrari, M.; Salameh, Z. Influence of Adaptation and Adhesion on the Retention of Computer-aided Design/Computer-aided Manufacturing Glass Fiber Posts to Root Canal. J. Contemp. Dent. Pract. 2019, $20,1004$.

39. Eid, R.Y.; Koken, S.; Baba, N.Z.; Ounsi, H.; Ferrari, M.; Salameh, Z. Effect of Fabrication Technique and Thermal Cycling on the Bond Strength of CAD/CAM Milled Custom fit Anatomical Post and Cores: An in Vitro Study. J. Prosthodont. 2019, 28, 898-905. [CrossRef] [PubMed]

40. Eid, R.; Juloski, J.; Ounsi, H.; Silwaidi, M.; Ferrari, M.; Salameh, Z. Fracture resistance and failure pattern of endodontically treated teeth restored with computer-aided design/computer-aided manufacturing post and cores: A pilot study. J. Contemp. Dent. Pract. 2019, 20, 56-63. [PubMed]

41. Ilie, N.; Hickel, R. Investigations on mechanical behaviour of dental composites. Clin Oral Investig 2009, 13, 427-438. [CrossRef] [PubMed]

42. Lohbauer, U.; Belli, R. The mechanical performance of a novel self-adhesive restorative material. J. Adhes. Dent. 2020, 22, 47-58.

43. Gusmão, G.M.; De Queiroz, T.V.; Pompeu, G.F.; Filho, P.F.; da Silva, C.V. The influence of storage time and $\mathrm{pH}$ variation on water sorption by different composite resins. Indian J. Dent. Res. 2013, 24, 60-65.

44. Zayeri, F.; Razmavar, S.; Naserinejad, K.; Akbarzadeh-Baghban, A.; Torabzadeh, H.; Salehi, M. Experimental Comparison of Hygroscopic Expansion in Three Different Composite Resins. J. Islam. Dent. Assoc. Iran 2012, 24, $35-42$.

45. Ghasemi, E.; Mosharraf, R.; Mirzaei, S. Comparison of water sorption of two injection acrylic resins with a conventional pressure-packed acrylic resin. J. Islam. Dent. Assoc. Iran. 2019, 31, 177-181. [CrossRef]

46. Azzam, R.S. Are the persistent symptoms to proton pump inhibitor therapy due to refractory gastroesopahgeal reflux disease or to other disorders? Arq. Gastroenterol. 2018, 55, 85-91. [CrossRef] 
47. Liebermann, A.; Wimmer, T.; Schmidlin, P.R.; Scherer, H.; Löffler, P.; Roos, M.; Stawarczyk, B. Physicomechanical characterization of polyetheretherketone and current esthetic dental CAD/CAM polymers after aging in different storage media. J. Prosthet. Dent. 2016, 115, 321-328.e2. [CrossRef]

48. Dos Santos, W.R.G.; de Brito, M.K.T.; de Lima, A.G.B. Study of the Moisture Absorption in Polymer Composites Reinforced with Vegetal Fiber Using Langmuir's Model. Mater. Res. 2019, 22, e20180848. [CrossRef]

49. Irari, K.W.; Moodley, D.S.; Patel, N. Effect of aging in artificial saliva on the shear bond strength of resin composite. S. Afr. Dent. J. 2018, 73, 617-622. [CrossRef]

50. Abdallah, A.J. Machinability of High-Strength Dental Polymers and Their Performance as Framework Materials for All-on-Four Prostheses. Ph.D. Thesis, Boston University, Boston, MA, USA, 2021.

51. Ruschel, G.H.; Gomes, É.A.; Silva-Sousa, Y.T.; Pinelli, R.G.P.; Sousa-Neto, M.D.; Pereira, G.K.R.; Spazzin, A.O. Mechanical properties and superficial characterization of a milled CAD-CAM glass fiber post. J. Mech. Behav. Biomed. Mater. 2018, 82, 187-192. [CrossRef] [PubMed]

52. Sfondrini, M.F.; Vallittu, P.K.; Lassila, L.; Viola, A.; Gandini, P.; Scribante, A. Glass Fiber Reinforced Composite Orthodontic Retainer: In Vitro Effect of Tooth Brushing on the Surface Wear and Mechanical Properties. Materials 2020, 13, 1028. [CrossRef] [PubMed]

53. Musanje, L.; Darvell, B.W. Aspects of water sorption from the air, water and artificial saliva in resin composite restorative materials. Dent. Mater. 2003, 19, 414-422. [CrossRef]

54. Thornton, I. Mechanical Properties of Dental Resin Composite CAD/CAM Blocks (T). Master's Thesis, University of British Columbia, Vancouver, BC, Canada, 2014. Available online: https://open.library.ubc.ca/collections/ubctheses/24/items/1.0167 584 (accessed on 13 October 2021).

55. Iftikhar, S.; Jahanzeb, N.; Saleem, M.; Rehman, S.; Matinlinna, J.P.; Samad Khan, A. The Trends of Dental Biomaterials Research and Future Directions: A Mapping Review. Saudi Dent. J. 2021, 33, 229-238. Available online: https:/ /www.sciencedirect.com/ science/article/pii/S101390522100002X (accessed on 19 October 2021). [CrossRef] 